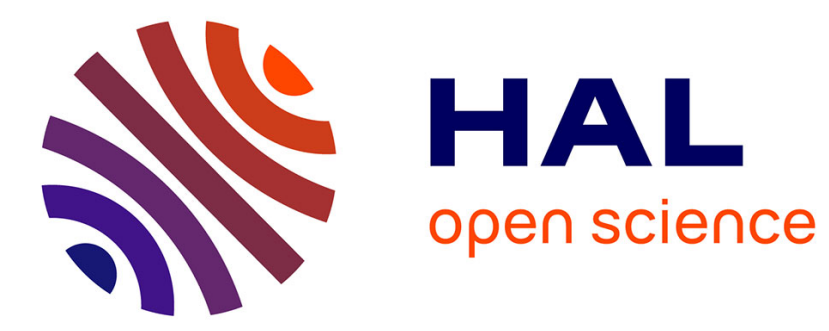

\title{
Proeryon, a geographically and stratigraphically widespread genus of polychelidan lobsters
}

Denis Audo, Günter Schweigert, Sylvain Charbonnier

\section{To cite this version:}

Denis Audo, Günter Schweigert, Sylvain Charbonnier. Proeryon, a geographically and stratigraphically widespread genus of polychelidan lobsters. Annales de Paléontologie, 2020, 106 (2), pp.102376. 10.1016/j.annpal.2019.102376 . hal-02547497

\section{HAL Id: hal-02547497 \\ https://hal.science/hal-02547497}

Submitted on 5 Jul 2021

HAL is a multi-disciplinary open access archive for the deposit and dissemination of scientific research documents, whether they are published or not. The documents may come from teaching and research institutions in France or abroad, or from public or private research centers.
L'archive ouverte pluridisciplinaire HAL, est destinée au dépôt et à la diffusion de documents scientifiques de niveau recherche, publiés ou non, émanant des établissements d'enseignement et de recherche français ou étrangers, des laboratoires publics ou privés. 


\title{
Proeryon, a geographically and stratigraphically widespread genus of polychelidan lobsters
}

Proeryon, un genre de langoustine Polychelida très répandu
géographiquement et stratigraphiquement

Denis Audo $^{\mathrm{a}, \mathrm{b}}$, Guenter Schweigert ${ }^{\mathrm{c}}$, Sylvain Charbonnier ${ }^{\mathrm{d}}$

\footnotetext{
${ }^{\mathrm{a}}$ Yunnan Key Laboratory for Palaeobiology, Yunnan University, North Cuihu road 2\#, 650091 Kunming (China) denis.audo@edu.mnhn.fr

b MEC International Joint Laboratory for Palaeobiology and Palaeoenvironment, Yunnan University (China)

'Staatliches Museum für Naturkunde, Rosenstein 1, 70191 Stuttgart (Germany) guenter.schweigert@smns-bw.de

${ }^{\mathrm{d}}$ Centre de Recherche en Paléontologie - Paris, (CR2P, UMR 7207), MNHN-Sorbonne Université-CNRS, Muséum national d’Histoire naturelle, 57 rue Cuvier F-75005 Paris (France)

sylvain.charbonnier@mnhn.fr
}

\begin{abstract}
Polychelidan lobsters are decapod crustaceans characterized by their four to five pairs of claws. The first description of a polychelidan lobster dates back to 1817 , and since then, numerous species have been described with varying level of details. This situation sometimes led to the description of synonymous species, and more generally, led to a lack of overview on the group systematic and evolutionary history. Herein, we review Proeryon, one of the most diversified and stratigraphically widespread polychelidan. We argue that Proeryon is closely allied to Tethyseryon and Gabaleryon and propose to assign them to Proeryoninae nov. subfam., which are mainly characterized by their hemicircular ocular incision, postorbital
\end{abstract}


and branchial carinae not joined together, and axial carina on pleonites cut by transverse grooves. Proeryon is in turn characterized by its marked cervical and hepatic incisions, simple posterolateral spines and arched uropodal exopod diaeresis. Thus defined, we assign the following species to Proeryon: P. charbonnieri, P. giganteus, P. hauffi, P. laticaudatus, P. richardsoni, P. stoddarti and two unnamed species from the Hauterivian of Germany and Switzerland, respectively. In addition, we refer to Proeryon, with some reservations, two new species, ?Proeryon quiltyi from the Callovian of Antarctica and ?Proeryon erinaceus from the Oxfordian of France. Proeryon has highly discontinuous but large stratigraphic (Pliensbachian-Hauterivian: about $60 \mathrm{MA}$ ) and palaeogeographic (from United Kingdom to Siberia, and to Antarctica) distribution. Most of these species occurs in relatively deep neritic or deeper palaeoenvironments. It is possible that this deep-sea dwelling is one of the reasons why Proeryon survived so long. Also, we note the presence of abundant oysters living as epibionts on some specimens of Proeryon hartmanni. Their disposition and number suggest that $P$. hartmanni was an epibenthic animal.

Key words : Eucrustacean, Decapoda, Palaeobiodiversity, stratigraphic range, Antarctica, Europe, Siberia

\section{RESUME}

Les Polychelida sont des crustacés décapodes caractérisés par la présence de quatre à cinq paires de pinces. La première espèce de Polychelida a été décrite en 1817 ; depuis, de nombreuses espèces ont été décrites avec plus ou moins en détails. Cette hétérogénéité a abouti à la description de nombreuses espèces synonymes, limitant notre compréhension de la systématique et de l'évolution des polychelida. Dans cet article, nous réétudions Proeryon, 
l'un des genres de polychelida les plus diversifiés et possédant une grande répartition stratigraphique. Proeryon semble proche de Tethyseryon et Gabaleryon; nous proposons donc de réunir ces trois genres au sein des Proeryoninae nov. subfam., caractérisés par une incision oculaire hémicirculaire, une carène postorbitaire distincte de la carène branchiale et la carène axiale des pléonites recoupée par les sillons transversaux. Proeryon se distingue par ses incisions cervicales et hépatiques marquées, ses épines postérolatérales simples et sa diérèse arquée sur l'exopode de l'uropode. Ainsi, nous incluons dans Proeryon les espèces suivantes : P. charbonnieri, P. giganteus, P. hauffi, P. laticaudatus, P. richardsoni, P. stoddarti et deux espèces de l'Hauterivien d’Allemagne et de Suisse restées en nomenclature ouverte. De plus, nous suggérons que ?Proeryon quiltyi du Callovien d'Antarctique et ?Proeryon erinaceus de l'Oxfordien de France sont également des Proeryon. La répartition stratigraphique (Plienbachien-Hauterivien) et paléogéographique (du Royaume Uni à la Sibérie) de Proeryon est très étendue mais également extrêmement discontinue. La plupart des espèces de Proeryon proviennent de paléoenvironnements néritiques assez profonds. Il est imaginable que la vie en milieux profonds soit une des raisons expliquant comment Proeryon a survécu si longtemps. D’autre part, nous notons d'abondantes huitres vivant en épibiontes sur certains spécimens de Proeryon hartmanni. Leur disposition et abondance suggèrent que $P$. hartmanni était un animal épibenthique.

Mots clés : Eucrustacés, Decapoda, Paléobiodiversité, extension stratigraphique, Antarctique, Europe, Sibérie 


\section{Introduction}

Polychelidan lobsters (also referred to as Eryonoidea Haan, 1841) are decapod crustaceans characterized by their four to five pairs of clawed pereiopods. They are discovered in various fossil environments, from shallow waters, as in the Solnhofen or Monte Fallano plattenkalks (Garassino and Schweigert, 2006; Bravi et al., 2014) to deep-water environments (Audo et al., 2014c; Audo et al., 2018a). Fossil representatives have been first described in the early 19th century (Desmarest, 1817), and since then, numerous species have been described by various authors, with varying level of details and terminology, leading to numerous taxonomic imprecisions and the description of synonymous species (see synonymy list of Cycleryon propinquus in Garassino and Schweigert, 2006 as a good example). These taxonomic issues prevent us to have a good overview of the diversity and evolutionary history of polychelidan lobsters. For these reasons, Audo’s (2014) unpublished $\mathrm{PhD}$ thesis included the first comprehensive systematic review of polychelidan lobsters. The present work is based upon Audo (2014) and an unpublished project by G. Schweigert, and propose a modern and updated systematic revision of one of the most diverse, geographically widespread, and longliving genus of polychelidan lobster: Proeryon Beurlen, 1928. We also describe two new species tentatively assigned to Proeryon and a further new species probably belonging to Eryonidae Haan, 1841 which co-occurs with Proeryon stoddarti (Woodward, 1881), with which it could be easily confused.

\section{Material and methods}

This work is based upon a total of 68 specimens (counting only one specimen in the case of multiple casts of the same specimen) listed in the systematic treatment of each species and in Appendix 1. Most specimens were directly studied, or, if this was not possible, they were studied based upon good quality, high-resolution photographs. In the case of ?Proeryon 
quiltyi sp. nov. and of Proeryon hartmanni (Meyer, 1836) illustrated in Schmidt-Kaler et al. (1992: fig. 47), we were unfortunately forced to study the specimen based upon the published illustrations only, since the original specimens could not be located in time.

To complement direct and microscope observations, some specimens were documented in cross-polarized photography. Cross-polarized photography is performed by illuminating the specimen with a polarized light source, mounting a polarizer on the camera lens, such as to cancel most of the light reflected directly from the specimen (Bengtson, 2000). This method increases considerably the contrast on the final picture, sometimes at the expense of reflections, which could provide information about the surface of the fossil. For this reason, photographs without cross-polarization have also been employed when necessary.

Specimens are stored in the following palaeontological collections:

- Bristol City Museum and Art Gallery (CMBK, Bristol, United Kingdom);

- Central Scientific Research Geological Survey Museum (CNIGR Museum, Saint Petersburg, Russia);

- Université Claude Bernard, Lyon 1 (FSL, Lyon, France);

- $\quad$ Natural History Museum (MHNG, Geneva, Switzerland)

- Muséum de Grenoble (MHNGr, Grenoble, France);

- Muséum national d’Histoire naturelle (MNHN.F, Paris, France);

- Museo Civico di Storia Naturale di Milano (MSNM, Milano, Italy);

- $\quad$ Natural History Museum (NHMUK, London, United Kingdom);

- Staatliches Museum für Naturkunde Stuttgart (SMNS, Stuttgart, Germany);

- Bayerische Staatssammlung für Paläontologie und Geologie (SNSB-BSPG, Munich, Germany);

- Université Grenoble-Alpes (UJF-ID, Grenoble, France); 
- Sorbonne Université (ex Université Pierre et Marie Curie) (UPMC, Paris, France);

- University of Tasmania, Rock Library and Geological Museum (UTGD, Hobart, Tasmania, Australia);

- The Wilson Cheltenham Art Gallery and Museum (Cheltenham, United Kingdom);

- Urweltmuseum Hauff (Holzmaden, Germany).

- Museum Werkforum of HOLCIM-Lafarge company (Dotternhausen, Germany)

- Private collection Helmut Tischlinger (Stammham, Germany).

- Private collection Dieter Weber (Rechberghausen, Germany)

The present work follows the cephalothoracic groove nomenclature proposed by Audo et al. (2018b). Anatomical abbreviations used in figures are presented in table 1.

\section{Systematic palaeontology}

Malacostraca Latreille, 1802

Decapoda Latreille, 1802

Pleocyemata Burkenroad, 1963

Polychelida Scholtz and Richter, 1995

Eryonoidea Haan, 1841

Coleiidae Van Straelen, 1925

Subfamily Proeryoninae nov. subfam. 
Included genera. Proeryon Beurlen, 1928 (type), Gabaleryon Audo, Williams, Charbonnier and Schweigert, 2017b, Tethyseryon Bravi, Garassino, Bartiroma, Audo, Charbonnier, Schweigert, Thévenard and Longobardi, 2014.

Occurrence. Pliensbachian (United Kingdom), Toarcian (France, Germany, Russia, United Kingdom), Bajocian-Bathonian (Italy), Bathonian (United Kingdom), Callovian (France, Antarctica), Oxfordian (France), Hauterivian (Germany, Switzerland).

Diagnosis. Ocular incision opening laterally; postorbital carina (if present) not joined to branchial carina; axial carina on pleonites cut by posterior transverse groove.

Remarks. Coleiidae are difficult to define precisely (Audo et al., 2014c), but within this apparently diffuse group, three genera seem to have close phylogenetic affinities: Proeryon, Gabaleryon and Tethyseryon which are easily distinguishable from other Coleiidae by their almost unique posterior transverse groove cutting the axial margin on pleonites (axial carina cutting transverse groove in other polychelidans, except in Palaeopolycheles longipes (Fraas, 1855), lack of a connection between the postorbital and branchial carinae (usually connected in other polychelidans) and their laterally open ocular incision (opening anteriorly in Polychelidae Wood Mason, 1874, protected by a large spine in other Coleiidae, sunken in the cephalothoracic shield in most Eryonidae).

Genus Proeryon Beurlen, 1928

Proeryon Beurlen, 1928: 191-193.

Eryon Lamarck, 1838: 376-377. Oppel, 1862: 8-10. Woodward, 1866: 494-495.

Coleia Van Straelen, 1925: 132-134. 
Proeryon Glaessner, 1929: 339. Glaessner, 1969: R470. De Grave, et al. 2009: 23. Schweitzer, et al. 2010: 44.

Type species. Eryon hartmanni Meyer, 1836, by subsequent designation of Glaessner (1929).

Included species. Proeryon charbonnieri Audo and Schweigert, 2018; P. giganteus Beurlen, 1930; P. hartmanni (Meyer, 1836); P. hauffi Beurlen, 1944; P. laticaudatus Beurlen, 1928; P. stoddarti (Woodward, 1881); probably P.richardsoni (Woodward, 1911), ?P. erinaceus sp. nov., ?P. quiltyi sp. nov., Proeryon sp1 and Proeryon sp2.

Occurrence. Pliensbachian (United Kingdom), Toarcian (France, Germany, Russia), Bathonian (United Kingdom), Callovian (France, Antarctica), Oxfordian? (France), Hauterivian (Germany, Switzerland).

Original diagnosis by Beurlen (1928). Der Cephalothorax ist breit und flach, das Verhältnis von Länge und Breite wechselt im Einzelnen sehr stark. Ein Rostrum fehlt, wie bei den Eryonidae überhaupt. Der Stirnrand ist schmal und eingebuchtet, seitlich ist er je durch eine Spitze gegen den Seitenrand begrenzt. Ganz vorn am Seitenrand hinter der Spitze des Frontallappens ist eine flache und breite Augenhöhle, in der die nicht gestielten Augen sitzen. Der Seitenrand ist stets weit ausgebaucht, auf seiner vorderen Hälfte mit 2 Einschnitten versehen. Er ist stets gezähnelt. Die größte Cephalothoraxbreite liegt hinter der Mitte. Die stark nach hinten ausgebogene, flache Nackenfurche zieht von dem vorderen seitlichen Einschnitt aus quer über den Cephalothorax. Eine dieser parallelen Furchen, die gewöhnlich noch viel flacher ist, tritt häufig auf, vom hinteren Einschnitt ausgehend. Die Mittellinie des Cephalothorax ist durch einen Längskamm gekennzeichnet, der ziemlich scharf, vom Hinterrand ausgehend, sich gegen vorn etwas verflacht und wenig vor der Nackenfurche häufig ganz verschwindet. Beiderseits von diesem Mittelkamm ist je noch ein weniger starker 
Längskamm, der gegen den Mittelkamm etwas geneigt, von hinten ausgehend, ungefähr in der Mitte der Cephalothoraxlänge ganz erlischt. Der Hinterrand des Cephalothorax ist breit und flach, er ist nur wenig eingebuchtet und mit einem flachen Wulst umgeben. Der Panzer ist stets ziemlich fein und dicht mit kleinen Wärzchen bedeckt.

Abdomen und Extremitäten weisen gegenüber den übrigen Eryoniden keinerlei Besonderheiten an. Die Abdominalsegmente sind durch zwei Querfurchen eingeteilt, in ein Vorderteil, ein in der Mitte am schmalsten seiendes Mittelstück und ein Hinterteil. Die Längskante des Cephalothorax setzt sich durch longitudinale Erhebungen über das ganze Abdomen bis zum Schwanz fort, die auf den Mittelstücken der einzelnen Segmente stehen, Die Scheren haben die bekannte typische schmale Form, wobei der Dactylopodit stets außen steht. Die Schwanzflosse hat keine Diäresis, sie ist im Einzelnen sehr verschieden geformt.

Translation of the Original diagnosis by Beurlen (1928). The cephalothorax is broad and flattened, the length/width ratio varies strongly in individual specimens. A rostrum is lacking, like in all Eryonidae. The frontal margin is narrow and concave, laterally it is bordered by a spine towards the lateral margin. Most distally at the lateral margin, posterior to the tip of the frontal lappet, there is a shallow and broad orbit bearing the unstalked eye. The lateral margin is always widely convex, bearing 2 incisions in its anterior half. It is always dentate. The maximum width of the cephalothorax is in a position posterior to the middle. The shallow, strongly posteriorly convex cephalic groove runs from the anterior lateral incision across the cephalothorax. One of the parallel grooves, which is usually much shallower, is often developed, starting from the posterior incision. The median line of the cephalothorax bears a longitudinal crest, which is relatively marked from the posterior margin and becomes anteriorly shallower until it often disappears in a short distance from the cephalic groove. On both lateral sides of that median crest there is another weaker longitudinal crest slightly narrowing the median crest anteriorly, running from posterior it disappears completely 
approximately at mid-length of the cephalothorax. The posterior margin of the cephalothorax is broad and flat, it is only weakly concave and bordered by a shallow bulge. The body is finely and densely covered with small papillae.

Pleon and pereiopods do not show any significant differences in comparison with other eryonids. The pleonal somites are subdivided by two cross grooves into an anterior field, a median field which is narrow in the centre, and a posterior field. The longitudinal crest of the cephalothorax continues on the entire pleon towards the tail by forming longitudinal elevations on the median fields of the somites. The chelae show the well-known typical tall shape, and the dactylus is always placed on the outer side. The tail fan lacks a diaeresis, it is of very different shape in different species.

Emended diagnosis by Glaessner (1969). Carapace with broadly V-shaped frontal margin and lateral shallow orbital indentation; lateral margins convex, widest behind middle; V-shaped parallel cervical and branchiocardiac grooves; endopodite of uropods truncated.

Emended diagnosis by Audo et al. (2014c). Dorsoventrally flattened carapace; large, slightly concave anterior margin; wide hemicircular ocular incisions; rounded posterolateral angle, extending along pleon; cervical groove curving backward near median line; cervical and postcervical grooves almost parallel between lateral margin and branchial carina; posterior transverse groove on pleonal tergites cutting median line; uropodal exopod with very curved diaeresis.

Emended diagnosis (present work). Dorsoventrally flattened carapace; large, slightly concave anterior margin; wide hemicircular ocular incisions; marked cervical and hepatic grooves, cervical incision being deeper; rounded posterolateral angle, extending along pleon; simple posterolateral spines (no small accessory spines arising on the shoulder of larger spines); cervical groove curving backward near median line; cervical and postcervical grooves 
almost parallel between lateral margin and branchial carina; posterior transverse groove on pleonal tergites cutting median line; uropodal exopod with very curved diaeresis.

Proeryon charbonnieri Audo and Schweigert, 2018

Fig. 1.

Proeryon charbonnieri Audo and Schweigert, 2018: 188-192, figs 3-5.

Eryon giganteus Van Straelen, 1923: 91, fig. 8. (pro parte), Balss, 1924: 175.

Coleia gigantea Van Straelen, 1925: 145-147, fig. 66, pl. 3, figs 4 (non fig. 3), pl. 4, figs 1-2. Roman, 1928: 109, fig. 18, pl. 3, fig. 4 (non fig. 1). Glaessner, 1929: 127. Charbonnier, 2009: 158-159, 163, figs 236, 244, 224-229, 393, 394, 399-401. Charbonnier et al., 2010: 115-117, figs 3c, 4c, 11a-c. (pro parte)

« Coleia » gigantea Charbonnier, et al. 2014: 375, table 1, fig. 4F.

Cyclocaris giganteus Pinna, 1968: 103.

Cycleryon gigantea (sic) Fischer, 2003: 241, fig. 27 (genus also misspelled as Glycerion and Cyclerion).

Proeryon giganteus Schweitzer et al., 2010: 44 (pro parte). Audo, 2014: 148-152, figs 48-50. Audo et al., 2014c: 505-509, Figs 2E, 6, 7.

Diagnosis. Dorsoventrally flattened cephalothoracic shield (carapace), with rounded, slightly pyriform outline in dorsal view; wider than long; frontal margin slightly concave; anterolateral angle forming a short oblique spine; ocular incision opening laterally cutting cephalothoracic shield in an arc of circle; small and triangular cervical and hepatic incisions; straight, elongate branchial carina, not merged to postorbital carina; lateral carina on branchial 
region; pleon half as wide as cephalothoracic shield; posterior transverse groove on pleonal terga cutting axial carina; exoskeleton densely tuberculate; subcircular and flattened scaphocerite; first pereiopod extremely long and slender; uropodal exopod with acutely curved diaeresis.

Type material. Holotype: UJF-ID 14023 (Fig. 1A-C). Paratypes: MSNM.i20703 (Fig. 1C); UJF-ID.11547, 11548-11549 (part and counterpart, 11550, 11552, 14020, 14051, 14052; FSL 170603, 170607-170609 (coll. Marin), 710080; MNHN.F.A50714, A50716A50719, A50726, A50741 (coll. Fischer), B11759; MHNGr.PA.10203, 10276; UPMC-248.

Additional specimens. FSL 170521, 170610 (coll. Caillet), 710081 (coll. Charbonnier), MNHN.F.A50713, A50727 (coll. Fischer), R03515 (cast); UJF-ID.14026, 14047-14049 (part and counterpart), 15050.

Type locality. Ravin des Mines near La Boissine, La Voulte-sur-Rhône Lagerstätte, Ardèche Department Rhône-Alpes, France.

Type age. Early Callovian, Macrocephalites gracilis ammonite Zone.

Distribution. Hitherto only known from the type locality.

Description. See Appendix 1 (updated from Audo and Schweigert, 2018).

Remarks. Proeryon charbonnieri is the most abundant and one of the largest polychelidans in La Voulte-sur-Rhône (Audo et al., 2014c, Audo and Schweigert, 2018). This species was previously confused with ?Soleryon giganteus (Van Straelen, 1923). Indeed, the type material of ?S. giganteus is composite and comprises much more specimens of P. charbonnieri than ?S. giganteus (among the survived type material, only the lectotype belongs to ?S. giganteus). For this reason, numerous reconstructions are composite (ex: Van Straelen, 1923: fig. 8, 1925: fig. 66; Fischer, 2003). For the same reason, Proeryon 
charbonnieri was ascribed erroneously to Proeryon giganteus (Van Straelen, 1923) (now ?Soleryon giganteus) by Audo et al. (2014c).

?Proeryon erinaceus sp. nov.

urn:lsid:zoobank.org:act:

Fig 2.

Diagnosis. Cephalothoracic shield rounded posteriorly, rather wide posteriorly and fringed by simple antrorse spines; no lateral carina visible on branchial region; pleon about half as wide as cephalothoracic shield; pleonites 1, 3-6 crossed by two transverse grooves cutting axial carina which forms large spines, including antrorse spines; exoskeleton dorsally covered by numerous tubercles and spines.

Etymology. Latin for hedgehog, refers to the high number and important size of spines on the exoskeleton.

Type material. Holotype by monotypy, FSL 170728, Caillet coll. (see endocast in Fig. 2).

Type locality. Calmoutier, Haute-Saône Department, Franche-Comté region, France.

Type age. Early Oxfordian of the Terrain à Chailles Formation (Argovian facies).

Description. See Appendix 1.

Remarks. The holotype lacks the anterior half of the cephalothoracic shield and the posterior part of the uropods on one side, and the entire uropod on the other side. The shape of its cephalothoracic shield, with its lateral expansions, the spiny lateral margins and marked 
branchial carina of this specimen indicate, however, it can be confidently ascribed to the Polychelida Scholtz and Richter, 1995.

The herein described new species possesses pleonite terga, on which the axial carina is cut deeply by a transverse groove, a disposition typical of Proeryoninae nov. subfam. Within Proeryoninae, the width of its cephalothoracic shield is more similar to that of Proeryon and Tethyseryon, Gabaleryon being narrower. It differs clearly from Tethyseryon by its simple (antrorse), small posterolateral spines similar one to each other (larger, with smaller accessory spines and of various sizes in Tethyseryon). We therefore ascribe it to Proeryon. Within Proeryon, it differs from all other species by the abundance of spines ornamenting its exoskeleton and the presence of antrorse spines on the axial carina of pleonites. For these reasons and taking into account the incompleteness of the holotype, we propose to describe this new species as ?Proeryon erinaceus sp. nov.

Despite its incompleteness, the holotype is among the specimens preserving most exquisitely the dorsal ornamentation of the exoskeleton, which is generally highly compressed in most other fossils.

Proeryon giganteus Beurlen, 1930.

Fig. 3.

Proeryon giganteus Beurlen, 1930: 219-222, fig. 1, pl. 15.

Proeryon zehentbaueri Audo et al., 2014c: 508. 
Proeryon giganteus Kuhn, 1952: 156, fig. 1. Hauff and Hauff, 1981: 86, fig. 112. Garassino and Gironi, 2005: 59. Audo and Schweigert, 2018: 192.

Proeryon laticaudatus Schweitzer et al., 2010: 44.

Proeryon zehentbaueri Audo, 2014: 168-170, fig. 59. Audo, et al. 2014c: 508.

Diagnosis. Species reaching a larger size than most other polychelidans; dorsoventrally flattened cephalothoracic shield, about as long as wide, with pyriform outline in ventral view and slightly curved lateral margins; shallow and wide frontal margin with a median indentation; anterolateral angle forming a short oblique spine; ocular incision opening laterally cutting cephalothoracic shield in an arc of circle; cervical and hepatic incisions marked but not very deep; posterolateral margin with simple antrorse spines; wide pleon (compared to cephalothorax width); axial carina on pleonites cut by the posterior transverse groove; first pereiopod elongated.

Type material. Holotype by monotypy, Urweltmuseum Hauff (Holzmaden, Germany), without collection number (Fig. 3).

Type locality. Holzmaden, Baden-Württemberg, Germany.

Type age. Lower Toarcian, Falciferum Zone, Posidonienschiefer Formation ('Posidonia Shale'), Untere Schiefer bed (Riegraf et al., 1984).

Description. See Appendix 1.

Remarks. Proeryon giganteus is assigned to Proeryon based upon its wide, rather shallow frontal margin with a median indentation, its pyriform cephalothoracic shield, its anterolateral angle forming a short spine oriented diagonally, its wide ocular incision opening laterally and cervical and hepatic incisions clearly marked but not very deep. Beurlen (1930) 
argued that $P$.giganteus is distinguishable from other species by its very large cervical incision. Our observation of the holotype suggests that what Beurlen (1930) interpreted as a cervical incision is actually an artefact linked to fractures of the cephalothoracic shield. The systematic list of fossil decapod by Schweitzer et al. (2010) considered P. giganteus to be synonymous with P. laticaudatus but they did not give their arguments for this proposed synonymy. Our present reinvestigation of species of Proeryon leads us to a different conclusion. We observe that P.giganteus differs from P. laticaudatus by its shorter anterolateral angle (longer in P. laticaudatus), its pyriform cephalothoracic shield (more ovoid in P. laticaudatus), and its wider pleon (narrower in P. laticaudatus). For these reasons we follow Audo et al. (2014c), who already considered P. giganteus as a distinct species. We also note that due to the unavailability of the type material of ?Soleryon giganteus (Van Straelen, 1923), Audo et al. considered that P. giganteus was a homonym of ?Soleryon giganteus (then assigned to Proeryon). This homonymy has since then been rejected following the rediscovery of the type material of ?Soleryon giganteus (see Audo and Schweigert, 2018).

We note that, as its name implies, $P$. giganteus is the biggest complete polychelidan lobster known to date. However, very large, incompletely preserved claws from the Early Jurassic of England (e.g., NHMUK 45101 with a dactylus measuring 55 mm and NHMUK I 2622 with a dactylus measuring $57 \mathrm{~mm}$ - compared to 39-41 mm for P. giganteus) prove that even larger specimens of potentially undescribed species existed.

Proeryon hartmanni (Meyer, 1836)

Figs 4-6. 
Eryon hartmanni Meyer, 1836: 263-270, pl. 9 fig. 1, pl. 12 fig. 2.

Eryon calvadosii Morière, 1883: 116-123, pls 1-3. nov. syn.

Eryon edwardsii Morière, 1864: 93-94, pl. 6 figs 1-3.

Proeryon longiceps Beurlen, 1928: 196-197, figs 22a-b.

Coleia macrophthalma Krause, 1891: 177-183, pl. 11 figs 1-4.

Proeryon viluensis Chernyshev, 1930: 375-384, pl. 1 figs 1, 3.

Eryon hartmanni Meyer, 1835: 329 (nomen nudum). M’Coy, 1849: 172. Meyer, 1856:

45. Oppel, 1862: 11. Morière, 1864: 92. Woodward, 1866: 501. Woodward, 1881: 530.

Morière, 1883: 119. Krause, 1891: 183. Knebel, 1907: 208. Woodward, 1911: 307. Balss, 1924: 175. Woods, 1925: 12.

Coleia hartmanni - Van Straelen, 1925: 141-142.

Proeryon hartmanni - Beurlen, 1928: 193, pl. 6 fig. 6. Glaessner, 1929: 339. Kuhn, 1952: 158, fig. 1. Secrétan, 1964: 119. Pinna, 1968: 104. Glaessner, 1969: 470. Hauff and Hauff, 1981: 86, fig. 109. Garassino and Gironi, 2005: 56. Ahyong, 2009: 375. Schweitzer, et al. 2010: 44. Audo, 2014: 153-161, figs 51-55. Audo et al., 2014c: 505. Audo, 2016: 291: fig. 3K. Audo, et al. 2016: table 3. Audo, et al. 2017a: 7: fig. 2K. Audo et al., 2017b: 208, fig. 3K. Audo et al., 2018b: 48: fig. 4K.

Proeryon hartmani Chernyshev, 1930: 376.

Eryon calvadosii Carter, 1886: 546. Renault, 1888: 14. Bate, 1888: xv (foreword). Krause, 1891: 176.

Eryon calvadosi Woodward, 1911: 307. Balss, 1924: 175. Bigot, 1945: 20.

Eryon Calvadoisi Woods, 1925: 12.

Proeryon edwardsi Kuhn, 1952: 159.

Coleia edwardsi Glaessner, 1929: 126. Karasawa et al., 2003: 358. Pinna, 1968: 108. Garassino and Gironi, 2006: 95. Teruzzi and Garassino, 2007: 95. Schweitzer et al., 2010: 44. 
Eryon edwardsii E. Eudes-Deslongchamps, 1868: 168. Woodward, 1866: 501.

Woodward, 1881: 530. Morière, 1883: 116. Carter, 1886: 546. Renault, 1888: 13. Balss, 1924: 175. Woodward, 1911: 307.

Proeryon longiceps Glaessner, 1929: 339. Kuhn, 1952: 157, fig. 1. Hauff and Hauff, 1981: 86, fig. 110. Schweigert and Dietl, 1999: 5.

Eryon macrophthalma Balss, 1924: 175.

Coleia macrophthalma Van Straelen, 1925: 140-141.

Proeryon macrophthalmus Beurlen, 1928: 193. Glaessner, 1929: 340. Kuhn, 1952:

158, fig. 1. Pinna, 1968: 104. Glaessner, 1969: 470, fig. 274 (3). Hauff and Hauff, 1981: 86.

Proeryon viluensis Kuhn, 1952: 159. Secrétan, 1964: 119. Aguirre-Urreta, et al. 1990: 160. Garassino and Gironi, 2005: 63. Schweitzer et al., 2010: 44.

Diagnosis. Dorsoventrally flattened cephalothoracic shield, with pyriform outline in dorsal view, about as long as wide; anterolateral angle forming a short spine orientated diagonally; small and triangular cervical and hepatic incisions; frontal margin slightly concave with a small median indentation; anterolateral angle forming a short spine orientated diagonally; ocular incision opening laterally cutting cephalothoracic shield in an arc of circle; cervical and hepatic incisions shallow; posterolateral margin with simple antrorse spines; straight, elongate branchial carina, not merged to postorbital carina; no lateral carina visible on branchial region; wide pleon (compared to cephalothorax); posterior transverse groove on pleonal terga cutting axial carina; exoskeleton densely tuberculate; subcircular scaphocerite; first pereiopod elongated; uropodal exopod with acutely curved diaeresis.

Type material. Holotype by monotypy, currently considered as lost, since it has not, for the moment, been found in major German museums. Fortunately, casts of good quality are still preserved in several museums. We therefore based our study on these casts: MNHN.F.A02720 (Fig. 4A), NHMUK 42010, SMNS 70478, MCZ IPAR 410.

\section{Type material of synonymized species:}

Eryon edwardsii. cast of holotype: MNHN.F.A46045 (see original illustration: Fig. 6A). 
Eryon calvadosii. casts of syntypes: MNHN.F.R03401 (Fig. 6B), and three cast in FSL collection, without collection numbers.

Coleia macrophthalma. two syntypes: MNHB X260 (Fig. 6C), X261.

Proeryon longiceps. two syntypes: one specimen, Hauff collection. (Holzmaden, Germany), no collection number (Fig. 6D); second syntype probably lost (not found in SMNS or Hauff collections).

Proeryon viluensis. syntypes: CNIGR Museum 2/2931 (Fig. 6E)- 5/2931.

Other material. SNSB-BSPG 1942 I 20. SNSB-BSPG without collection number. SMNS 8266, 64010. 4 specimens in Hauff collection (Holzmaden, Germany), without collection number. One specimen in Dieter Weber's private collection (Rechberghausen, Germany) (Fig. 4C). One specimen in Helmut Tischlinger's private collection (Stammham, Germany; Figs 5A-B). One specimen from the Werkforum (Dotternhausen), without coll. number.

Type locality. Göppingen-Holzheim, Baden-Württemberg, Germany.

Type age. Lower Toarcian, Falciferum Zone, Posidonienschiefer Formation ('Posidonia Shale').

Distribution. Toarcian (Germany, France, Russia).

Description. See Appendix 1.

\section{Remarks:}

Variance in the shape of first pereiopod propodus. There is a distinct variability in the shape of the propodus of the first pereiopod (thoracopod 4): it can be rather elongated (as in the holotype Fig. 4A-B) or much shorter (Fig. 4C-D). Besides, on one specimen from the 
Koblenzer bed (Weber collection, Rechberghausen), the surface of the propodus appears to be covered by a scale-like ornamentation. These differences are, however, to date not sufficient to distinguish several species or clear morphotypes within $P$. hartmanni. Indeed, is the case of the length or the propodus of the first pereiopod, intermediates exist between the specimens with a long propodus and those with a shorter propodus. Distinguishing morphotypes on the ornamentation alone is also unpractical, because the surface ornamentation of the propodus is only clear on one specimen, on some other, the surface appears to be smooth, but this may well be linked to preservation.

Case of the Normandy polychelidans. Three species from the Toarcian of Normandy (France) are known. Among these, two, Eryon edwardsii Morière, 1864 (Fig. 6A) and Eryon calvadosii Morière, 1883 (Fig. 6B) seem to be species of Proeryon.

Eryon edwardsii (Fig. 6A) is described based upon a well-preserved pleon and posterior part of cephalothoracic shield, which retained its original volume. The holotype, which was housed in the Université de Caen was destroyed at the end of the Second World War (Bigot, 1945). Fortunately, a good-quality cast is still available in the MNHN collections (MNHN.F.A46045). Our reinvestigation of E. edwardsii based upon this cast allows the following observations: the postrostral carina is well-marked and ornamented with a single row of tubercles; pleonites axial carina is deeply incised by posterior transverse groove; s2-s4 tergopleura are mucronate, s5 tergopleuron seems to have a concave lateral margin. This pleon does not present any visible differences with that of Proeryon hartmanni.

Eryon calvadosii (Fig. 6B), recovered from the same outcrop (La Caine, Calvados, France) as E. edwardsii is much more complete, although it was highly flattened during diagenesis. This species is described based upon three syntypes: (1) one subcomplete specimen, with its pleon folded so that it is only partially visible; (2) a poorly preserved 
cephalothoracic shield associated to an unfolded pleon, allowing the observation of the entire pleon, telson and uropods; (3) a pleon associated with the telson, but lacking its uropods. These three specimens were housed in the Université de Caen collections and, as the E. edwardsii holotype, were destroyed at the end of WWII. As for E. edwardsii, good-quality casts are still available and are housed in the FSL and MNHN collections. Unfortunately, they correspond to specimens with "cosmetic improvements”, (i.e., partial reconstructions), which complicate the study of the true morphology in E. calvadosii. We nevertheless observe that the cephalothoracic shield has an outline similar to that of $P$. hartmanni, the pleon is also very similar, whereas the frontal margin seems completely different from that of $P$. hartmanni and any other polychelidans; the latter aspect, however, suggests it was artificially altered; carinae and grooves are also identical to that of P. hartmanni; P1 are unnaturally straight, and probably correspond to another "cosmetic improvement” of the fossil.

A last polychelidan species, E. morieri Renault, 1888 has been described from the Jurassic of Normandy. This species is represented by several fragments, which, as the type material of E. edwardsii and E. calvadosii, were destroyed at the end of WWII since they were probably housed in the Université de Caen collections. In this case, no cast of the type material has been discovered, so we can only rely on the original illustrations of Renault (1888: pls 1-2). These figures show fragments of fossils which do not display any evident traits allowing an ascription to arthropods. The fragment which Renault (1888) considered as a cephalothoracic shield resembles, as seen from the illustration, to the inner mould of a bivalve shell. Due to the lack of information provided by the original illustrations and the loss of type material, we propose to consider E. morieri as a nomen dubium.

As explained, E. edwardsii and E. calvadosii both come from the same outcrop. Both species have no visible differences separating them and were already considered as synonymous by Glaessner (1929) and Pinna (1968). Considering the aforementioned lack of 
distinctive character between both species, we agree with Glaessner (1929) and Pinna (1968) and consider both species synonymous. In addition, we propose to synonymise these two species with $P$. hartmanni, which cannot be distinguished from them. These three species are therefore synonyms, and Proeryon hartmanni (Meyer, 1836) as the first described species has the priority.

Case of Coleia macrophthalma (Fig. 6C). This species was described by Krause (1891) based upon four fragmentary syntypes: (1) a cephalothoracic shield (MNHB X260), (2) an isolated pleonite (MNHB X261), (3) a pleon in lateral view and (4) a subcomplete first pereiopod. These last two specimens have not been found and are probably lost. Following the opinion of numerous authors (Beurlen, 1928; Glaessner, 1929; Kuhn, 1952; Pinna, 1968; Glaessner, 1969), we assign Coleia macrophthalma to Proeryon based on its pyriform cephalothoracic shield, the frontal margin with a small median indentation, the anterolateral angle forming a short spine and its marked but shallow cervical and hepatic incisions. Within Proeryon, P. macrophthalmus only differs from P. hartmanni by its proportionally larger ocular incision and smaller size. These two differences can easily be explained if we consider the specimens of $P$. macrophthalmus as juvenile specimens of $P$. hartmanni. We therefore concur with Garassino and Gironi (2005) and Schweitzer et al. (2010) and consider P. macrophthalmus as a junior synonym of $P$. hartmanni.

Case of Proeryon longiceps (Fig. 6D). This species was described based upon two specimens from the Lower Toarcian of Baden-Württemberg (Germany). The examination of the syntypes housed in the Hauff collection (Holzmaden, Germany) does not allow identifying any major differences with $P$. hartmanni. Beurlen (1928) justified the erection of P. longiceps by its slightly longer carapace and straighter lateral margin. However, these two characteristics of $P$. longiceps appear to be well in the range of variation exhibited by P. hartmanni, especially taking into account slight deformations linked to diagenesis and 
ontogenetic variations (as for P. macrophthalmus). For these reasons, we agree with Garassino and Gironi (2005) and Schweitzer et al. (2010) to consider P. longiceps as a junior synonym of $P$. hartmanni.

Case of Proeryon viluensis (Fig. 6E). Proeryon viluensis was described by Chernyshev (1930) based upon four syntypes (CNIGR Museum 2/2931 to 4/2931: two subcomplete specimens, one cephalothoracic shield fragment and an isolated first pereiopod). The examination of high resolution photographs of the subcomplete specimens did not reveal any significant differences with $P$. hartmanni. Chernyshev (1930) suggested that $P$. viluensis was closely allied to P. hartmanni differing only by a more anteriorly placed cervical groove and a tail fan (= telson + uropods) resembling more that of P. laticaudatus. We were unfortunately unable to observe these differences and therefore propose to synonymize P. viluensis with $P$. hartmanni.

Proeryon hauffi Beurlen, 1944

Fig. 7.

Proeryon hauffi Beurlen, 1944: 375-377, fig. 1a-b.

Proeryon hauffi Kuhn, 1952: 157, fig. 1. Hauff and Hauff, 1981: 86. Garassino and Gironi, 2005: 59. Audo, 2014: 162-163, fig. 56. Audo et al., 2014c: 505.

Proeryon laticaudatus Schweitzer et al., 2010: 44.

Diagnosis. Dorsoventrally flattened cephalothoracic shield (carapace), with ovoid outline in dorsal view; longer than wide; wide, slightly concave frontal margin without a small median indentation; anterolateral angle forming a short spine orientated anteriorly; ocular incision laterally and cutting cephalothoracic shield in an arc of circle; shallow cervical and hepatic incisions; branchial carina long and straight not merged to postorbital carina; no 
lateral carina visible on branchial region; wide pleon (compared to cephalothoracic shield); posterior transverse groove on pleonal terga cutting axial carina; exoskeleton densely tuberculate on cephalic region; subcircular scaphocerite with a thin median carina.

Type material. Holotype by monotypy, SNSB-BSPG 1942 i 17 (Fig. 7).

Type locality. Holzmaden, Baden-Württemberg, Germany.

Type age. Lower Toarcian, Falciferum Zone; Posidonienschiefer Formation (“Posidonia Shale”), Schieferklotz bed (Riegraf et al., 1984).

Description. See Appendix 1.

Remarks. Proeryon hauffi is assigned to Proeryon based upon its wide, slightly concave frontal margin, its ocular incision opening widely laterally, cervical and hepatic incisions marked but not deep and pleonites with axial carina cut deeply by the posterior transverse grooves. This species is distinguished from $P$. laticaudatus by its cephalothoracic shield slightly longer (slightly shorter in P. laticaudatus), shallower cervical and hepatic incisions (deeper in P. laticaudatus) and anterolateral angle forming a short spine (longer in P. laticaudatus). Proeryon hauffi is also distinguished from all other species by its much narrower (longer than wide) cephalothoracic shield, and postcervical groove not curving forward near the median line.

Proeryon laticaudatus Beurlen, 1928

Fig. 8.

Proeryon laticaudatus Beurlen, 1928: 198-199, fig. 23.

Proeryon banzensis Kuhn, 1952: 156-159, pl. 13 figs 1-2, pl. 14 fig. 1, pl. 15 fig. 1. (nov. syn.). 
Proeryon laticaudatus Glaessner, 1929: 339. Chernyshev, 1930: 380. Kuhn, 1952: 157, fig. 1. Pinna, 1968: 104. Hauff and Hauff, 1981: 86. Garassino and Gironi, 2005: 63. Schweitzer et al., 2010: 44. Audo, 2014: 164-166, fig. 57. Audo et al., 2014c: 505. Coleia banzensis Garassino and Teruzzi, 2001: 190. Karasawa et al., 2003: 357. Proeryon hartmanni Garassino and Gironi, 2005: 57. Schweitzer et al., 2010: 44.

Diagnosis. Dorsoventrally flattened cephalothoracic shield (carapace), with ovoid outline in dorsal view; longer than wide; wide, slightly concave frontal margin with a small median indentation; anterolateral angle forming a spine orientated diagonally; ocular incision laterally and cutting cephalothoracic shield in an arc of circle; shallow cervical and hepatic incisions; no lateral carina visible on branchial region; wide pleon (compared to cephalothoracic shield); posterior transverse groove on pleonal terga cutting axial carina; exoskeleton densely tuberculate; subcircular scaphocerite; first pereiopod elongated; uropodal exopod with acutely curved diaeresis.

Type material. Lectotype (herein designated): Urweltmuseum Hauff coll. without coll. number (Fig. 8, illustrated by Beurlen, 1928: fig. 23b). Paralectotype: Urweltmuseum Hauff coll. without coll. number (illustrated by Beurlen, 1928: fig. 23a).

Type locality. Holzmaden, Baden-Württemberg, Germany.

Type age. Lower Toarcian, Falciferum Zone; Posidonienschiefer Formation (“Posidonia Shale”) (Riegraf et al., 1984).

Description. See Appendix 1.

Remarks. Proeryon laticaudatus was described based upon two syntypes housed in the Urweltmuseum Hauff. Our reinvestigation of these two specimens reveals that the second one figured by Beurlen (1928: fig. 23b) possesses an elongated anterolateral angle which is unique within Proeryon and is not visible on the second specimen. In the interest of nomenclatural stability, we propose to designate this second specimen (Fig. 8A-B) as the 
lectotype of $P$. laticaudatus, since this specimen, although being the more fragmentarily preserved one, shows clear diagnostic character allowing the identification of the species.

Proeryon laticaudatus is assigned to Proeryon based upon its wide frontal margin slightly concave and with a median indentation, its ocular incision widely opens laterally, its cervical and hepatic incisions marked but shallow and pleonites in which the axial carina is cut by the posterior transverse groove. Proeryon laticaudatus was distinguished based upon its cephalothoracic shield more elongated than that of other Proeryon species and its telson which, following Beurlen (1928) has a truncated posterior margin. However, after observing carefully the specimen, we think Beurlen (1928) was probably misled about the shape of telson by the poor preservation of its posterior part. Actually, a small fragment of the telson tip shows that the telson was originally subtriangular, as in other Proeryon species.

The ratio between the length and width of the cephalothoracic shield of P. laticaudatus are quite similar to that of $P$. hauffi, with which it has been synonymized (e.g., Schweitzer et al., 2010). We, however, disagree with this synonymy as P. laticaudatus differs clearly from P. hauffi by its longer anterolateral angle (shorter in P.hauffi), its less elongated cephalothoracic shield (slightly longer in P. hauffi), and its slightly deeper cervical and hepatic incisions.

Proeryon laticaudatus is clearly distinguishable from other Proeryon by its elongated anterolateral angle and narrower cephalothoracic shield.

Case of Proeryon banzensis. Proeryon banzensis Kuhn, 1952 has been synonymized with P. hartmanni by Garassino and Gironi (2005) and Schweitzer et al. (2010). We consider that by its proportions, $P$. banzensis is more similar to $P$. laticaudatus. Since no character on the poorly preserved $P$. banzensis allows distinguishing it from $P$. laticaudatus, we propose to consider these two species as synonyms. 
?Proeryon quiltyi sp. nov.

Fig. 9.

“Eryon” Laudon et al., 1969: folio 12, plate 3.

Cycleryon sp. Quilty, 1977: 1033. Quilty, 1988: 619-622, figs 2.1-2.6, not 2.7.

Diagnosis. Dorsoventrally flattened cephalothoracic shield (carapace), with subcircular outline in dorsal view; about as long as wide; deep cervical groove curving backward before cutting deeply median line; pleon distinctly narrower than cephalothoracic shield; telson with a marked median carina and lateral margin forming a distinct large spine near its base.

Etymology. The specific epithet honours the late New Zealand palaeontologist Patrick G. Quilty, who discovered and first studied the material of ?Proeryon quiltyi.

Type material. Holotype: UTGD 87123 (pleonites 3-6 and telson: fig. 9A-9B). Paratype: UTGD 87425 (cephalothoracic shield and parts of the pleonites 1-3:fig. 9C-D).

Locality. $3.3 \mathrm{~km}$ northeast of Mt. Irman, Behrendt Mountains, Ellsworth Land, Antarctica (Quilty 1988).

Age. Middle Jurassic, Callovian? (Quilty, 1988).

Description. See Appendix 1.

Remarks. ?Proeryon quiltyi was initially described as Eryon Desmarest, 1817. This assignment should probably not be regarded as an actual assignment to Eryon but rather as a statement that it was recognized as a polychelidan lobster. Subsequently, the overall shape of the cephalothoracic shield and shallow cephalothoracic grooves led to the assignment of this 
species to Cycleryon Glaessner, 1965. Our examination of Quilty (1988)’s illustrations leads us to another conclusion. Indeed, the posterior transverse groove clearly cuts the axial carina on the pleonites, one of the key characters of Proeryoninae which is unknown in eryonids such as Cycleryon. Besides, the outline of cephalothoracic shield is comparable to that of several species of Proeryon and to Tethyseryon campanicus. Shallow cephalothoracic grooves are not surprising within Proeryoninae either, as Proeryon hartmanni for instance has rather shallow cephalothoracic grooves. In fact, one of the syntypes of P. calvadosii (= P. hartmanni) presents an aspect very similar to that of the species from Antarctica herein discussed. We therefore propose to assign this species to Proeryoninae. Quilty (1988) had noticed the unusual shape of the telson, compared to that of other species of Cycleryon. It indeed possesses a marked median carina and lateral margins forming distinct large spines near their bases. The morphology of the telson is as far as we know unique to this species. Considering the shape of the cephalothoracic shield, ?Proeryon quiltyi could fit within Tethyseryon and Proeryon. The precise generic assignment at this point is difficult to solve: the preservation of the specimens is not sufficiently good to observe additional characters which would suggest ?P. quilty is closely related to one of these two genera, or should be assigned to its own genera. Since we cannot distinguish traces of the prominent spines typical of Tethyseryon, we propose to assign it provisionally within Proeryon. Besides, Proeryon having shown the greatest geographic and stratigraphic extension, Proeryon might be a better candidate than Tethyseryon.

Proeryon richardsoni (Woodward, 1911)

Fig. 10 .

Eryon richardsoni Woodward, 1911: 307-311, fig. 2. 
Eryon richardsoni Balss, 1924: 175.

Coleia richardsoni Woods, 1925: 21, pl. 6 fig. 2. Van Straelen, 1925: 140.

Proeryon richardsoni Kuhn, 1952: 159. Pinna, 1968: 104.

Proeryon hartmanni Garassino and Gironi, 2005: 56. Schweitzer et al., 2010: 44.

?Proeryon richardsoni Audo, 2014: 171-173, fig. 60.

Diagnosis. Dorsoventrally flattened cephalothoracic shield (carapace), with subcircular outline in dorsal view; about as long as wide; wide, slightly concave frontal margin; ocular incision lateral and cutting the cephalothoracic shield in an arc of circle; deep cervical and hepatic incisions; posterolateral margin with simple antrorse spines; branchial carina long and straight not merged to postorbital carina; no lateral carina visible on branchial region; pleon distinctly narrower than cephalothoracic shield; exoskeleton densely tuberculate on cephalic region.

Type material. Holotype by monotypy, No. F685 (Fig. 10A) stored at The Wilson Cheltenham Art Gallery and Museum.

Other material. A single other specimen BGS IDA 225874 (Fig. 10B) is known and comes from the type locality (Woods, 1925).

Type locality. Dumbleton hill, near Beckford, Gloucestershire, United Kingdom.

Type age. Pliensbachian (Woods, 1925).

Description. See Appendix 1.

Remarks. Proeryon richardsoni is known from only two incomplete specimens from Dumbleton hill (Gloucestershire, United Kingdom). We assign this species to Proeryon based 
upon its ocular incision opening laterally, pleonites in which the posterior transverse groove appears to cut the axial carina, its small cervical and hepatic incisions and its subcircular carapace. This assignment agrees with the opinions of Woods (1925) (who considered it closely allied to P. hartmanni), Kuhn (1952), Pinna (1968), Garassino and Gironi (2005) and Schweitzer et al. (2010). Comparison of this species with other species of Proeryon is difficult due to the poor preservation of available material. We note that the subcircular shape of the carapace distinguishes it from at least P. giganteus, P. hauffi and P. laticaudatus. Furthermore, this species is the stratigraphically the oldest known species of Proeryon dating back to the Pliensbachian.

Proeryon stoddarti (Woodward, 1881)

Fig. 11.

Eryon stoddarti Woodward, 1881: 529-530, pl. 14 fig. 2.

Eryon stoddarti Woodward, 1911: 307. Balss, 1924: 175. Woods, 1925: 23, pl. 6 fig. 3. Glaessner, 1929: 167. Secrétan, 1964: 118.

Proeryon stoddarti Pinna, 1968: 104. Garassino and Gironi, 2005: 59. Schweitzer et al., 2010: 44. Audo, 2014: 167-168, fig. 58.

Diagnosis. Dorsoventrally flattened cephalothoracic shield (carapace), with pyriform outline in dorsal view; wider than long; wide, slightly concave frontal margin with a small median indentation; ocular incision lateral and cutting cephalothoracic shield in an arc of circle; anterolateral angle forming a short spine orientated diagonally; deep cervical and hepatic incisions; posterolateral margin with simple antrorse spines; branchial carina long and straight; no lateral carina visible on the branchial region; no postorbital carina visible along the ocular incision; pleon distinctly half as wide as cephalothoracic shield; posterior 
transverse groove on pleonal terga cutting axial carina; exoskeleton densely tuberculate on cephalic region.

Type material. Holotype by monotypy, CMBK C2625, Stoddart coll. (Fig. 11)

Type locality. Stonesfield, Oxfordshire, United Kingdom.

Type age. Bathonian, following Boneham and Wyatt (1993).

Description. See Appendix 1.

Remarks. Proeryon stoddarti is assigned to Proeryon based upon its ocular incision widely opening laterally, its anterolateral angle forming a spine orientated diagonally and pleonites in which the axial carina is cut by the posterior transverse groove. This species is easily distinguished from other Proeryon species by its lack of postorbital carina.

\section{Proeryon sp.1}

Fig. 12.

Eryon sp. Van Straelen, 1936: 1-2, pl. 1 fig. 1. Schweigert and Herd, 2010: fig. 3.

Material. MHNG-GEPI-028368 (Fig. 12).

Locality. “Feradzo”, near Châtel-Saint-Denis, Fribourg, Switzerland.

Age. Neocomian, from the "Néocomien à Céphalopodes” facies (most likely bed of the Faraoni Anoxic Event of the Late Hauterivian, see Baudin et al., 2006).

Description. See Appendix 1.

Remarks. This species is represented by a single fragmentary specimen missing the anterior and lateral parts of cephalothoracic shield and all appendages save for one uropodal 
endopod. Van Straelen (1936), who published the first description of this specimen interpreted the cephalothoracic shield as elongated and narrow. He apparently did not notice that what he interpreted as the marginal carinae were actually the branchial carinae, and that the cephalothoracic shield extended beyond these carinae.

Considering that the axial carina of pleonites is cut by the posterior transverse grooves, and that the cephalothoracic shield appears rather wide, this species seems to belong either to Proeryon or Tethyseryon, the former being more probable as the pleon appears quite narrow, as that of P. charbonnieri and P. stoddarti, and contrary to that of Tethyseryon which is almost as wide as the cephalothorax is mature specimens (Bravi et al., 2014).

\section{Proeryon sp.2}

Fig. 13.

Proeryon sp. Schweigert and Herd, 2010: 212-217, fig. 4.

Proeryon n. sp. Frerichs, 2010: 330, unnumbered figure.

Material. SMNS 66141 (Fig. 13).

Locality. Claypit Resse near Hannover, Lower Saxony, Germany.

Age. Early Cretaceous, Late Hauterivian.

Description. See Appendix 1.

Remarks. This species is known from two incomplete specimens representing a pleon. Schweigert and Herd (2010) attributed the first find to Proeryon. A second, even more incomplete specimen from the same locality has been recorded from a private collection soon after the publication of the first one (Frerichs, 2010). Our observation reveals that the 
posterior transverse groove of pleonites cutting the axial carina is indeed typical of Proeryoninae. The generic attribution is, however, more complex to establish as the cephalothoracic shield is completely missing. We therefore provisionally follow Schweigert and Herd (2010) and leave this species attributed to Proeryon.

This species is the youngest precisely dated Proeryoninae known.

?Eryonidae Haan, 1841

Genus Stonesfielderyon gen. nov.

Fig. 14.

Eryon Woods, 1925: 23, pl. 7 fig. 1.

Type species. Stonesfielderyon imitator sp. nov.

Included species. Only the type species is currently known.

Occurrence. Middle Jurassic, Bathonian (United Kingdom).

Diagnosis. Dorsoventrally flattened carapace; large, slightly concave anterior margin; wide ocular incisions opened anteriorly and laterally; deep cervical and hepatic incisions; hepatic incision deeper than cervical incision; rounded posterolateral angle, extending along pleon and adjacent to the first pleonite tergopleuron; cervical groove interrupted by axial carina; posterior transverse groove on pleonal tergites indistinct.

Remarks. Stonesfielderyon gen. nov. bears close resemblance to Eryonidae based upon its axial carina interrupting the cervical groove (as in other Eryonidae and in Palaeopentachelidae Ahyong, 2009; but unlike Coleiidae, Tetrachelidae Beurlen, 1930, and Polychelidae, in which the cephalothoracic groove cuts deeply the axial line), cervical groove 
straight near the median line (as in other Eryonidae, curved in most other polychelidans), the double row of tubercles on the axial carina of the cephalothoracic shield (single row in many Proeryoninae, double row in many Eryonidae) and its hepatic incision deeper than the cervical incision (as in Eryonidae; cervical incision deeper in most Coleiidae). It appears to differ from Palaeopentachelidae by its shorter anterolateral angle (forming an acute spine in Palaeopentacheles). Due to the overall preservation of the single known specimen however, other of the most diagnostic characters of Eryonidae, such the unarticulated uropodal exopod (= no diaeresis) and position of the anterior part of the branchial carina are unfortunately not visible. We also notice that the posterolateral angle appears to be adjacent to the lateral margin of s1, a character generally not observed in Eryonidae. For all these reasons, we only tentatively assign Stonesfielderyon to Eryonidae. Among Eryonidae, Stonesfielderyon differs from all other genera by: (1) its posterolateral angle extending along to the first pleonite and adjacent to the pleon (extending along first pleonite but separated from the pleon by a space in Eryonidae); and (2) the wide ocular incision opening laterally (smaller ocular incision opening obliquely in other Eryonidae except Knebelia). It also differs from Knebelia by its frontal margin with a simple, unarticulated, anterolateral angle (with articulated frontal lobes in Knebelia), from Eryon by its straight anterolateral margin (concave in Eryon) and Cycleryon by its shorter telson (more elongated in Cycleryon).

Stonesfielderyon imitator sp. nov.

Fig. 14.

Eryon sp. Woods, 1925: 23, pl. 7 fig. 1.

Type material. Holotype by monotypy, FSL 170531 (Fig. 14). 
Type locality. Stonesfield, Oxfordshire, United Kingdom.

Type age. Bathonian, following Boneham and Wyatt (1993).

Description. See Appendix 1.

Remarks. Stonesfielderyon imitator possesses a striking resemblance in its outlines to the co-occurring Proeryon stoddarti. However, it differs from Proeryon by some important key aspects, most of which were already mentioned by Woods (1925): (1) the axial carina (merging of postrostral and postcervical carinae) cutting cervical groove (cervical groove deeply cutting axial carina carina in P. stoddarti); (2) the apparent smooth posterolateral margin of the cephalothoracic shield (with small spines in P. stoddarti); (3) the smooth pleonites (with axial tubercles or short carinae and transverse grooves in P. stoddarti).

\section{DISCUSSION}

Diversity. Our taxonomic revision of Proeryon reveals it is, after Coleia Broderip, 1835, the secondmost diverse genus of polychelidan lobsters, with up to 11 species on a total of 66 species of polychelidan lobsters (nomina dubia and nomina nuda not included: see Appendix 2). In the case of Coleia, the morphological diversity of the genus may give hints that Coleia as it is currently considered (e.g. see Schweitzer et al., 2010) is not monophyletic. By contrast, Proeryon is supported by a distinct set of characters suggesting it forms a natural, monophyletic group.

Stratigraphic distribution. Proeryon is also one of the longest living genera of polychelidan lobsters: about 60 MA from the earliest occurrence (Pliensbachian-Hauterivian). Coleia may have had a yet longer stratigraphic extension (Carnian to Early Cretaceous: Karasawa et al., 2003, Garassino et al., 2012), but its currently imprecise diagnostic characters 
cast some doubts about the generic assignments of some species currently recognized as Coleia.

Geographic distribution. Our systematic work shows that Proeryon occurs from United Kingdom to Siberia, most specimens being discovered in southern Germany. This geographic distribution is probably a mere relict of a much greater distribution. Indeed, large gaps in distribution occur: fossils of Proeryoninae (possibly Proeryon) are also present in Antarctica, which was already extremely far from Europe during the Middle Jurassic (Seton et al., 2012); yet no other species of Proeryoninae has been reported from Gondwana.

\section{Palaeoecology:}

Palaeodepth and stratigraphic distribution. Audo et al. (2014c) speculated that the long stratigraphic distribution of Proeryon is perhaps a result of its relatively deep-water lifehabits favoured by a greater stability of these environments which may be less prone to perturbations by eustatic oscillations. Audo et al. (2014c) did not have the opportunity to review precisely the origin of each known species of Proeryon, which we should attempt herein:

- Proeryon richardsoni may have lived in a quite shallow environment, as Dumbledon Hill is also known for yielding insects (Williams et al., 2015). Unfortunately, the precise stratigraphic information or formation, from which P. richardsoni was extracted, are unknown; for this reason, great doubts remain on the palaeoenvironment of this species.

- The Proeryon species from the Toarcian Posidonia Shale come from a neritic environment, with a depth ranging from 50 to 150 metres (Röhl et al., 2001).

- Proeryon stoddarti from the Bathonian comes from a quite shallow environment, from the inner shelf to lower shoreface. 
- The palaeoenvironment of Proeryon charbonnieri from the Callovian of La Voultesur-Rhône is generally considered as deep (deposited on the continental slope or deeper: Charbonnier, 2009; Charbonnier et al., 2010, 2014), however, at least one species suggests it was in the euphotic zone (Vannier et al., 2016), but this species may well have come from a nearby shallower environment (Audo et al., 2019).

- ?Proeryon quiltyi from the Callovian of Ellsworth land is associated with a pelagic fauna (Quilty, 1977, 1988).

- $\quad$ ?Proeryon erinaceus from the Oxfordian of south-eastern France probably lived in a palaeoenvironment a few hundred of metres deep (Charbonnier et al., 2012).

- Proeryon sp.1 from the Hauterivian of the Ultrahelvetic Units of western Switzerland is most likely related to a moderately deep pelagic setting with anoxia conditions favourable for the preservation of delicate fossils (Baudin et al., 2006).

- Proeryon sp.2 from the Hauterivian of Resse near Hannover, as ?P. quiltyi is associated to numerous pelagic taxa (Frerichs, 2001; Nungesser, 2008).

Although the estimation of palaeodepth is here quite imprecise, we remark the frequent occurrence of Proeryon in relatively deep-water settings from the Toarcian onward. Besides, Proeryon does not occur in two distinctly shallow-water palaeoenvironments where other polychelidans used to live: the Bajocian-Bathonian of Monte Fallano (Bravi et al., 2014) and the Kimmeridgian-Tithonian of the well-studied Solnhofen Archipelago (Barthel et al., 1990; Garassino and Schweigert, 2006). The assumption of Audo et al. (2014c) might therefore be justified.

Insights of life habits. Two species of Proeryon are represented by enough wellpreserved specimens to be studied from a palaeoecological perspective: Proeryon charbonnieri and P. hartmanni. 
The mode of life of $P$. charbonnieri was discussed in Audo et al. (2014c) (although the species was mistakenly referred to as "Proeryon giganteus"): by comparison with extant polychelids and other crustaceans, it is supposed that with its elongated first pereiopod, it may have been well-suited to catch small nectobenthic preys (Audo et al., 2014c).

By contrast, P. hartmanni, as other species of Proeryon for which the first pereiopod is known, has shorter and thicker first pereiopods. It was therefore probably less adapted to hunt for small nectobenthic preys than P. charbonnieri. However, compared to P. charbonnieri, it was probably capable of crushing and cut sturdier food elements. More importantly, Proeryon hartmanni is one the rare species of polychelidan lobsters with epibionts, the other being Voulteryon parvulus Audo et al., 2014c (Audo et al., 2019) with attached brachiopods, Soleryon amicalis Audo et al., 2014a (Audo et al., 2014a) with what appears to be an attached coral, and Palaeopentacheles roettenbacheri (Münster, 1839) with attached serpulid worm tubes. In the case of P.hartmanni, one specimen in Helmut Tischlinger’s collection (Fig. 5A-B) has several small Liostrea falcifera (Quenstedt, 1856), oysters attached on the posterior part of carapace and left uropodal endopod. This specimen is not unique as another specimen in the museum "Werkforum" in Dotternhausen is similarly covered with oysters, and specimen SMNS 64010 also possess a few epibionts on the first pereiopod.

Considering how polychelidan lobsters are supposed to bury themselves into the sediment (Firth and Pequegnat, 1971, see also Jauvion et al., 2016 fig. 6), it appears that Proeryon hartmanni probably did not bury itself, since doing so would undoubtedly have prevented the attachment and growth of attached oysters. This aspect is important, because Ahyong (2009) suggested that polychelidans showed a trend to adopt a fossorial lifestyle: this shows that Proeryon hartmanni either was more primitive in this aspect or secondarily lost this adaptation. Also, contrary to Knebelia bilobata (Münster, 1839), which possesses a thin 
exoskeleton and was possibly a decent swimmer (Audo et al., 2014b), Proeryon hartmanni, with its thicker exoskeleton, and so burdened with numerous oysters was probably epibenthic. Since oysters are filter feeders, we can easily imagine $P$. hartmanni as living, at least for some individuals in agitated water where oysters would find enough suspended food. Although it was undoubted benthic, P. hartmanni nevertheless could become the prey of large pelagic vertebrates, and at least one fossil of $P$. hartmanni was reported (as Eryon edwardsii) within the stomach of an ichthyosaur (Eudes-Deslongchamps, 1868). Unfortunately, this fossil was probably destroyed during the Second World War together with much of the Caen University palaeontological collection (Bigot, 1945).

\section{Conclusion}

Our reinvestigation of Proeryon shows that with nine to eleven species, it is one of the most diverse genera of polychelidan lobsters. Proeryon was an evolutionary success, which survived at least from the Pliensbachian to the Hauterivian and colonized environments from Siberia to United Kingdom, possibly going as far as Antarctica.

\section{Acknowledgments}

We are pleased to acknowledge the precious help of curators and other people involved with palaeontological collections that helped us access fossils or sent us good quality photographs: Abel Prieur, Emmanuel Robert (Université Lyon 1, Villeurbanne, France), Fabienne Giraud (Université Grenoble-Alpes, Grenoble, France), Claudie Durand, Armand Fayard and Rebecca Bilon (Muséum de Grenoble, Grenoble, France), Alessandro Garassino (MSNM, Milano, Italy), Isabelle Rouget (MNHN, Paris, France), Jean-Michel Pacaud (MNHN, Paris, France), Lionel Cavin and Pierre-Alain Proz (Muséum d'Histoire naturelle, Geneva, Switzerland), Rolf Bernhard Hauff (Urweltmuseum Hauff, Holzmaden, Germany), Claire 
Mellish (NHMUK, London, United Kingdom), Deborah Hutchinson and Roger Vaughan (Bristol City Museum and Art Gallery), Paul J. Shepherd, Louise Neep and Michael P.A. Howe (British Geological Survey), Aleksey Sokolov (Central Scientific Research Geological Survey Museum, Saint Petersburg, Russia), Isabella J. von Lichtan and Patrick Quilty (University of Tasmania, Saint Petersburg, Tasmania, Australia), Javier Ortega-Hernández (Harvard University, Harvard, USA) to volunteers and staff of the Wilson Cheltenham Art Gallery and Museum (Cheltenham, United Kingdom). We are indebted to private fossil collectors, who gave us access to their collections: Helmut Tischlinger (Stammham, Germany) and Dieter Weber (Rechberghausen, Germany). We are thankful to Robert O’Flynn (YKLP, Kunming, China) for improving the English. We thank Gérard Breton (Le Havre, France) for his careful review of the present research; DA research was supported by the China Postdoctoral Science Foundation, Yunnan Province Postdoctoral Science Foundation, NSFC grant 41861134032, and Yunnan Provincial Research Grants 2018FA025 and 2018IA073.

\section{References}

Aguirre-Urreta, M.B., Buatois, L.A., Chernoglasov, G.C.B., Medina, F.A., 1990. First Polychelidae (Crustacea, Palinura) from the Jurassic of Antarctica. Antarctic Science 2, 157-162. https://doi.org/10.1017/S0954102090000207

Ahyong, S.T., 2009. The Polychelidan Lobsters: Phylogeny and Systematics (Polychelida : Polychelidae). In: Martin, J.W, Crandall, K.A., Felder, D.L. (Eds.), Decapod Crustacean Phylogenetics. Crustacean Issues 18, pp. 369-396.

Audo, D., 2014. Les Polychelida, un groupe de crustacés énigmatiques : systématique, histoire évolutive, paléoécologie et paléoenvironnements. Unpublished $\mathrm{PhD}$ thesis, Muséum national d'Histoire naturelle, Paris (298р.).

Audo, D., 2016. Tonneleryon, a new gregarious polychelidan lobster from the early Toarcian Posidonia Shale of Holzmaden (Germany). Neues Jahrbuch für Geologie und 
Paläontologie

Abhandlungen

280 ,

285-298.

https://dx.doi.org/10.1127/njgpa/2016/0580

Audo, D., Charbonnier, S., Krobicki, M., 2018a. Rare fossil polychelid lobsters in turbiditic palaeoenvironments. Journal of Systematic Palaeontology 16, 1017-1036. https://dx.doi.org/10.1080/14772019.2017.1359690

Audo, D., Charbonnier, S., Schweigert, G., Saint Martin, J.-P., 2014a. New eryonid crustaceans from the Late Jurassic Lagerstätten of Cerin (France), Canjuers (France), Wattendorf (Germany) and Zandt (Germany). Journal of Systematic Palaeontology 12, 459-479. http://dx.doi.org/10.1080/14772019.2013.777809

Audo, D., Haug, J.T., Haug, C., Charbonnier, S., Schweigert, G., Müller, C.H.G., Harzsch, S., 2016. On the sighted ancestry of blindness - exceptionally preserved eyes of Mesozoic polychelidan lobsters. Zoological Letters 2 (13), 1-20. https://dx.doi.org/10.1186/s40851-016-0049-0

Audo, D., Hyžný, M., Charbonnier, S., 2018b. The early polychelidan lobster Tetrachela raiblana and its impact on the homology of carapace grooves in decapod crustaceans. Contribution to Zoology 87, 41-57. http://www.ctoz.nl/vol87/nr01/a04

Audo, D., Schweigert, G., Haug, J.T., Haug, C., Saint Martin, J.-P., Charbonnier, S., 2014b. Diversity and palaeoecology of the enigmatic genus Knebelia (Eucrustacea, Decapoda, Eryonidae) from Upper Jurassic plattenkalks in southern Germany. Palaeontology 57, 397-416. http://dx.doi.org/10.1111/pala.12071

Audo, D., Schweigert, G., 2018. Large polychelidan lobsters with a rounded carapace from the Middle Jurassic La Voulte-sur-Rhône Lagerstätte: taxonomic clarifications. Geodiversitas 40, 183-194. https://doi.org/10.5252/geodiversitas2018v40a9

Audo, D., Schweigert, G., Saint Martin, J.-P., Charbonnier, S., 2014c. High biodiversity in Polychelida crustaceans from the Jurassic La Voulte-sur-Rhône Lagerstätte. Geodiversitas 36, 489-525. https://dx.doi.org/10.5252/g2014n4a1

Audo, D., Schweigert, G., Charbonnier, S., Haug, J.T., 2017a. Systematic revision and palaeobiology of Rosenfeldia triasica and Rogeryon oppeli nov. gen., nov. comb. (Eucrustacea, Polychelida). European Journal of Taxonomy 367, 1-23. https://doi.org/10.5852/ejt.2017.367

Audo, D., Robin, N., Luque, J., Krobicki, M., Haug, J.T., Haug, C., Jauvion, C., Charbonnier, S., 2019. Palaeoecology of Voulteryon parvulus (Eucrustacea, Polychelida) from the Middle Jurassic of La Voulte-sur-Rhône Fossil-Lagerstätte. Scientific Reports 9 (5332). https://dx.doi.org/10.1038/s41598-019-41834-6 
Audo, D., Williams, M., Charbonnier, S., Schweigert, G., 2017b. Gabaleryon, a new genus of widespread early Toarcian polychelidan lobsters. Journal of Systematic Palaeontology 15, 205-222. https://dx.doi.org/10.1080/14772019.2016.1167786

Balss, H., 1924. Studien an fossilen Decapoden II. Paläontologische Zeitschrift 6, 174-184. https://doi.org/10.1007/BF03041598

Barthel, K.W., Swinburne, N.H.M., Conway Morris, S., 1990. Solnhofen. A study in Mesozoic palaeontology. Cambridge University Press, Cambridge (236 p.).

Bate, C.S., 1888. Report on the Crustacea Macrura collected by H.M.S. Challenger during the years 1873-1876. In: Wyville Thomson, C., Murray, J. (Eds), Report on the scientific results of the voyage of the H.M.S. Challenger during the years 1873-76 under the command of Captain Georges S. Nares R.N., F.R.S. and the late Captain Frank Tourle Thomson, R.N. Zoology. Volume 24. Neill, Edinburgh (i-cx, 942 p.).

Baudin, F., Busnardo, R., Beltran, C., de Rafelis, M., Renard, M., Charollais, J., Clavel, B., 2006. Enregistrement de l'événement anoxique Faraoni (Hauterivien supérieur) dans le domaine ultrahelvétique. Revue de Paléobiologie 25, 525-535.

Bengtson, S., 2000. Teasing fossils out of shales with cameras and computers. Palaeontologia Electronica 3 (Art. 4), 1-14.

Beurlen, K., 1928. Die Decapoden des Schwäbischen Jura mit Ausnahme der aus den oberjurassischen Plattenkalken stammenden. Beiträge zur Systematik und Stammesgeschichte der Decapoden. Palaeontographica 70, 115-278.

Beurlen, K., 1930. Nachträge zur Decapodenfauna des Schwäbischen Jura. Neues Jahrbuch für Mineralogie, Geologie und Paläontologie, Beilage-Bände 64, 219-234.

Bigot, A., 1945. La destruction des collections et des bibliothèques scientifiques de Caen. Bulletin de la Société Linnéenne de Normandie volume supplémentaire année 1945, 175.

Boneham, B.F.W., Wyatt, R.J., 1993. The stratigraphical position of the Middle Jurassic (Bathonian) Stonesfield Slate of Stonesfield, Oxfordshire, UK. Proceedings of the Geologists Association 104, 123-136.

Bravi, S., Garassino, A., Bartiromo, A., Audo, D., Charbonnier, S., Schweigert, G., Thévenard, F., Longobardi, C., 2014. Middle Jurassic Monte Fallano Plattenkalk (Campania, southern Italy): first report on terrestrial plants, decapod crustaceans and fishes. Neues Jahrbuch für Geologie und Paläontologie Abhandlungen 272, 79-107. http://dx.doi.org/10.1127/0077-7749/2014/0398 
Carter, J., 1886. On the decapod crustaceans of the Oxford Clay. Quarterly Journal of the Geological Society 42, 542-559. https://doi.org/10.1144/GSL.JGS.1886.042.01-04.55

Charbonnier, S., 2009. Le Lagerstätte de La Voulte : un environnement bathyal au Jurassique. Mémoires du Muséum national d'Histoire naturelle 199, 1-272.

Charbonnier, S., Audo, D., Caze, B., Biot, V., 2014. The La Voulte-sur-Rhône Lagerstätte (Middle Jurassic, France). Comptes Rendus Palevol 13, 369-381. http://dx.doi.org/10.1016/j.crpv.2014.03.001

Charbonnier, S., Pérès, D., Letenneur, C., 2012. Exceptionally preserved crustaceans from the Oxfordian of eastern France (Terrain à Chailles Formation, Haute-Saône). Geodiversitas 34, 531-568.

Charbonnier, S., Vannier, J., Hantzpergue, P., Gaillard, C., 2010. Ecological significance of the arthropod fauna from the Jurassic (Callovian) La Voulte Lagerstätte. Acta Palaeontologica Polonica 55, 111-132. http://dx.doi.org/10.4202/app.2009.0036

Chernyshev, B., 1930. New Eryonidae from Vilui River. Izvestija Vsesojuznoe geologorazuedochinoe upavlenie 49, 375-384 [in Russian]

De Grave, S., Dean Pentcheff, N., Ahyong, S.T., Chan, T.-Y., Crandall, K.A., Dworschak, P.C., Felder, D.L., Feldmann, R.M., Fransen, C.H.J.M., Goulding, L.Y.D., Lemaitre, R., Low, M.E.Y., Martin, J.W., Ng, P.K.L., Schweitzer, C.E., Tan, S.H., Tshudy, D., Wetzer, R., 2009. A classification of living and fossil genera of decapod crustaceans. Raffles Bulletin of Zoology Supplement 21, 1-109.

Desmarest, A.-G., 1817. Crustacés fossiles, In: Société de Naturalistes et d’Agriculteurs (Eds), Nouveau Dictionnaire d’Histoire naturelle, appliquée aux Arts, à l’Agriculture, à l’Économie rurale et domestique, à la Médecine, etc. 7. Déterville, Paris, pp. 495519.

Eudes-Deslongchamps, E., 1868. Note sur des céphalopodes et des crustacés renfermés dans la cavité abdominale de poissons et de reptiles des argiles infraoolithiques. Bulletin de la Société Linnéenne de Normandie Série 2, 1, 156-169.

Firth, R.M., Pequegnat, W.E., 1971. Deep-sea lobsters of the families Polychelidae and Nephropidae (Crustacea, Decapoda) in the Gulf of Mexico and Caribbean Sea, Texas A\&M University, Department of Oceanography (106 p.).

Fischer, J.-C., 2003. Invertébrés remarquables du Callovien inférieur de La Voulte-sur-Rhône (Ardèche, France). Annales de Paléontologie 89, 223-252.

Frerichs, U., 2001. Die Tongrube Resse - mehr als nur Ammoniten. Arbeitskreis Paläontologie Hannover 29, 61-75. 
Frerichs, U., 2010. „Ein Vielscherer aus der Unterkreide“. Fossilien 2010 (6), 330.

Garassino, A., Gironi, B., 2005. Proeryon hartmanni (v. Meyer, 1835) (Crustacea, Decapoda, Eryonoidea) and Archaeopalinurus cfr. A. levis Pinna, 1974 (Crustacea, Decapoda, Palinuroidea) from the Lower Jurassic (Toarcian) of Cesana Brianza-Suello (Lecco, N Italy). Atti della Società italiana di Scienze naturali e del Museo civico di Storia naturale in Milano 146, 53-68.

Garassino, A., Gironi, B., 2006. Coleia boboi n. sp. (Crustacea, Decapoda, Eryonoidea) from the Late Triassic (Rhaetian) of Monte Verzegnis (Udine, NE Italy). Atti della Società italiana di Scienze naturali e del Museo civico di Storia naturale in Milano 147, 93102.

Garassino, A., Pini, G.A., Pasini, G., 2012. First report of a polychelid lobster (Crustacea: Decapoda: Coleiidae) from the Early Cretaceous of Italy. Neues Jahrbuch für Geologie und Paläontologie Abhandlungen 263, 47-55. http://dx.doi.org/10.1127/0077$\underline{7749 / 2012 / 0209}$

Garassino, A., Schweigert, G., 2006. The Upper Jurassic Solnhofen decapod crustacean fauna: review of the types from old descriptions. Part I. Infraorders Astacidea, Thalassinidea, and Palinura. Memorie della Società Italiana di Scienze Naturali e del Museo Civico di Storia Naturale di Milano 34, 1-64.

Garassino, A., Teruzzi, G., 2001. I crostacei decapodi del Toarciano (Giurassico inferiore) di Sogno (Bergamo, N Italia). Atti della Società italiana di Scienze naturali e del Museo civico di Storia naturale in Milano 141, 187-197.

Glaessner, M.F., 1929. Crustacea Decapoda. In: Pompeckj F.J. (ed.), Fossilium Catalogus I: Animalia, Pars 41. W. Junk, Berlin, pp. 1-464.

Glaessner, M.F., 1969. Decapoda. In: Moore, R.C., Teichert, C. (Eds), Treatise on Invertebrate Paleontology, Part R. Arthropoda, 4 (2). Geological Society of America, Boulder, Colorado and University of Kansas Press, Lawrence, Kansas, pp. R400R533.

Hauff, B., Hauff, R.B., 1981. Das Holzmadenbuch. Hauff-Stiftung, Holzmaden (136 p.).

Jauvion, C., Audo, D., Charbonnier, S., Vannier, J., 2016. Virtual dissection and lifestyle of a 165-million-year-old female polychelidan lobster. Arthropod Structure and Development 45, 122-132. https://doi.org/10.1016/j.asd.2015.10.004

Karasawa, H, Takahashi, F, Doi, E., Ishida, H., 2003. First notice of the family Coleiidae Van Straelen (Crustacea: Decapoda: Eryonoidea) from the upper Triassic of Japan. Paleontological Research 7, 357-362. http://dx.doi.org/10.2517/prpsj.7.357 
Knebel, W., von, 1907. Die Eryoniden des oberen Weissen Jura von Süddeutschland. Archiv für Biontologie 2, 195-233.

Krause, P.G., 1891. Die Decapoden des norddeutschen Jura. Zeitschrift der Deutschen Geologischen Gesellschaft 43, 171-225.

Kuhn, O., 1952. Neue Crustacea Decapoda und Insecta aus dem untersten Lias $\varepsilon$ von Nordfranken. Palaeontographica, Abteilung A 101, 153-166.

Lamarck, J.-.B. de, 1838. Histoire naturelle des animaux sans vertèbres 5, Renouard, Paris, (699 p.).

Laudon, T.S., Lackey, L.L., Quilty, P.G., Otway, P.M., 1969. Geology of Eastern Ellsworth Land. Antarctic Map Folio Series 12.

M’Coy, F., 1849. On the Classification of some British Fossil Crustacea, with Notices of new Forms in the University Collection at Cambridge. The Annals and Magazine of Natural History, second series 4 (21), 161-179.

Meyer, H., von, 1835. Mittheilungen, an Professor Bronn gerichtet. Neues Jahrbuch für Mineralogie, Geognosie, Geologie und Petrefaktenkunde 1835, 328-329.

Meyer, H., von, 1856. Jurasische und Triasische Crustaceen. Palaeontographica 4, 44-55.

Morière, J., 1864. Note sur les crustacés fossiles des terrains jurassiques du Calvados. Bulletin de la Société Linnéenne de Normandie 8, 89-96.

Morière, J., 1883. Note sur une Eryonidée nouvelle trouvée à la Caine (Calvados). Bulletin de la Société Linnéenne de Normandie $3^{\mathrm{e}}$ Série 7, 116-122.

Nungesser, K., 2008. Mikrofossilien aus den Aegocrioceras-Schichten der Tongrube Resse/Niedersachsen. Online: $\quad$ https://www.steinkern.de/praeparation-undbergung/fundorte/niedersachsen/183-mikrofossilien-aus-den-aegocrioceras-schichtender-tongrube-resse-niedersachsen.html accessed on 17th February 2019.

Oppel, A., 1862. Ueber jurassische Crustaceen (Decapoda macrura). Palaeontologische Mittheilungen aus dem Museum des koeniglich Bayerischen Staates 1, 1-120.

Pinna, G., 1968. Gli Erionidei della nuova fauna sinemuriana a crostacei decapodi di Osteno in Lombardia. Atti della Società italiana di Scienze naturali e del Museo civico di Storia naturale in Milano 107, 93-134.

Quilty, P.G., 1977. Late Jurassic bivalves from Ellsworth Land, Antarctica: Their systematics and paleogeographic implications. New Zealand Journal of Geology and Geophysics 20, 1033-1080. https://doi.org/10.1080/00288306.1977.10420696

Quilty, P.G., 1988. Cycleryon Glaessner (Crustacea, Decapoda) from the Jurassic of Ellsworth Land, Antarctica. Journal of Paleontology 62, 619-622. 
Renault, C., 1888. Note sur une eryonidée nouvelle trouvée à Sainte-Honorine-la- Guillaume (Orne) dans le grès liasique. Bulletin de la Société Linnéenne de Normandie Série 4, 2, 13-19.

Riegraf, W., Werner, G., Lörcher, F., 1984. Der Posidonienschiefer. Biostratigraphie, Fauna und Fazies des südwestdeutschen Untertoarciums (Lias ع). Enke Verlag, Stuttgart, 1195.

Röhl, H.-J., Schmid-Röhl, A., Oschmann, W., Frimmel, A., Schwark, L., 2001. The Posidonia Shale (Lower Toarcian) of SW-Germany: an oxygen-depleted ecosystem controlled by sea level and palaeoclimate. - Palaeogeography, Palaeoclimatology, Palaeoecology 165, 27-52.

Roman, F., 1928. 1. Horizon à nodules de crustacés et poissons. In: Sayn, G., Roman, F. (Eds), Monographie stratigraphique et paléontologique du Jurassique moyen de La Voulte-sur-Rhône. Travaux du laboratoire de géologie de la faculté des sciences de Lyon 11 (13), 1-165.

Schmidt-Kaler, H., Tischlinger, H., Werner, W., 1992. Wanderungen in die Erdgeschichte (4) Sulzkirchen und Sengenthal - zwei berühmte Fossilfundstellen am Rande der Frankenalb. Munich (Dr. F. Pfeil) (112 p.).

Schweigert, G., Dietl, G., 1999. Neubeschreibung von ‘Eryon longipes O. Fraas’ (Crustacea, Decapoda, Eryonidea) aus dem Nusplinger Plattenkalk (Ober-Kimmeridgium, Schwäbische Alb). Stuttgarter Beiträge zur Naturkunde, Serie B 274, 1-19.

Schweigert, G., Herd, K.J., 2010. Ein Vielscherer aus der Unterkreide. Fossilien 27, 212-217. Schweitzer, C.E., Feldmann, R.M., Garassino, A., Karasawa, H., Schweigert, G., 2010. Systematic list of fossil decapod crustacean species. Crustaceana Monographs 10, 1222. 
Secrétan, S., 1964. Les Crustacés décapodes du Jurassique supérieur et du Crétacé de Madagascar. Mémoires du Muséum national d’Histoire naturelle, Nouvelle série, Série C, Sciences de la Terre 14, 1-226.

Seton, M., Müller, R.D., Zahirovic, S., Gaina, C., Torsvik, T., Shephard, G., Talsma, A., Gurnis, M., Turner, M., Maus, S., Chandler, M., 2012. Global continental and ocean basin reconstructions since 200Ma. Earth-Science Reviews 113, 212-270. https://dx.doi.org/10.1016/j.earscirev.2012.03.002

Teruzzi, G., Garassino, A., 2007. Coleia Broderip, 1835 (Crustacea, Decapoda, Coleiidae) from the Mesozoic of Italy: an update, In: Garassino A., Feldmann R.M., Teruzzi G. (eds), 3rd Symposium on Mesozoic and Cenozoic decapod crustaceans. Memorie della Società Italiana di Scienze Naturali e del Museo Civico di Storia Naturale di Milano 35, 95-96.

Vannier, J., Schoenemann, B., Gillot, T., Charbonnier, S., Clarkson, E., 2016. Exceptional preservation of eye structure in arthropod visual predators from the Middle Jurassic. Nature Communications 7, 10320. https://dx.doi.org/10.1038/ncomms10320

Van Straelen, V., 1923. Description de Crustacés décapodes macroures nouveaux des terrains secondaires. Annales de la Société royale zoologique de Belgique 53, 84-93.

Van Straelen, V., 1925. Contribution à l'étude des crustacés décapodes de la période jurassique. Mémoires de la Classe des Sciences de l’Académie royale de Belgique 7, $1-462$.

Van Straelen, V., 1936. Crustacés Décapodes nouveaux ou peu connus de l'époque crétacique. Bulletin du Musée royal d’Histoire naturelle de Belgique 12 (45), 1-50, pls 1-4.

Williams, M., Benton, M.J., Ross, A., 2015. The Strawberry Bank Lagerstätte reveals insights into Early Jurassic life. Journal of the Geological Society 172, 683-692. https://dx.doi.org/10.1144/jgs2014-144

Woods, H., 1925-1931. A monograph of the fossil macrurous crustacean of England. The Palaeontographical Society, London, pp. 1-122.

Woodward, H., 1866. Notes on the species of the genus Eryon Desmarest from the Lias and Oolite of England and Bavaria. Quarterly Journal of the Geological Society 22, 494502.

Woodward, H., 1881. Contribution to the study of Fossil Crustacea. The Geological Magazine New series Decade II 8 (12), 529-534. 
Woodward, H., 1911. On a new species of Eryon from the Upper Lias, Dumbleton Hill. The Geological Magazine New series Decade V 8 (7), 307-311.

\section{Figure captions}

Fig. 1.

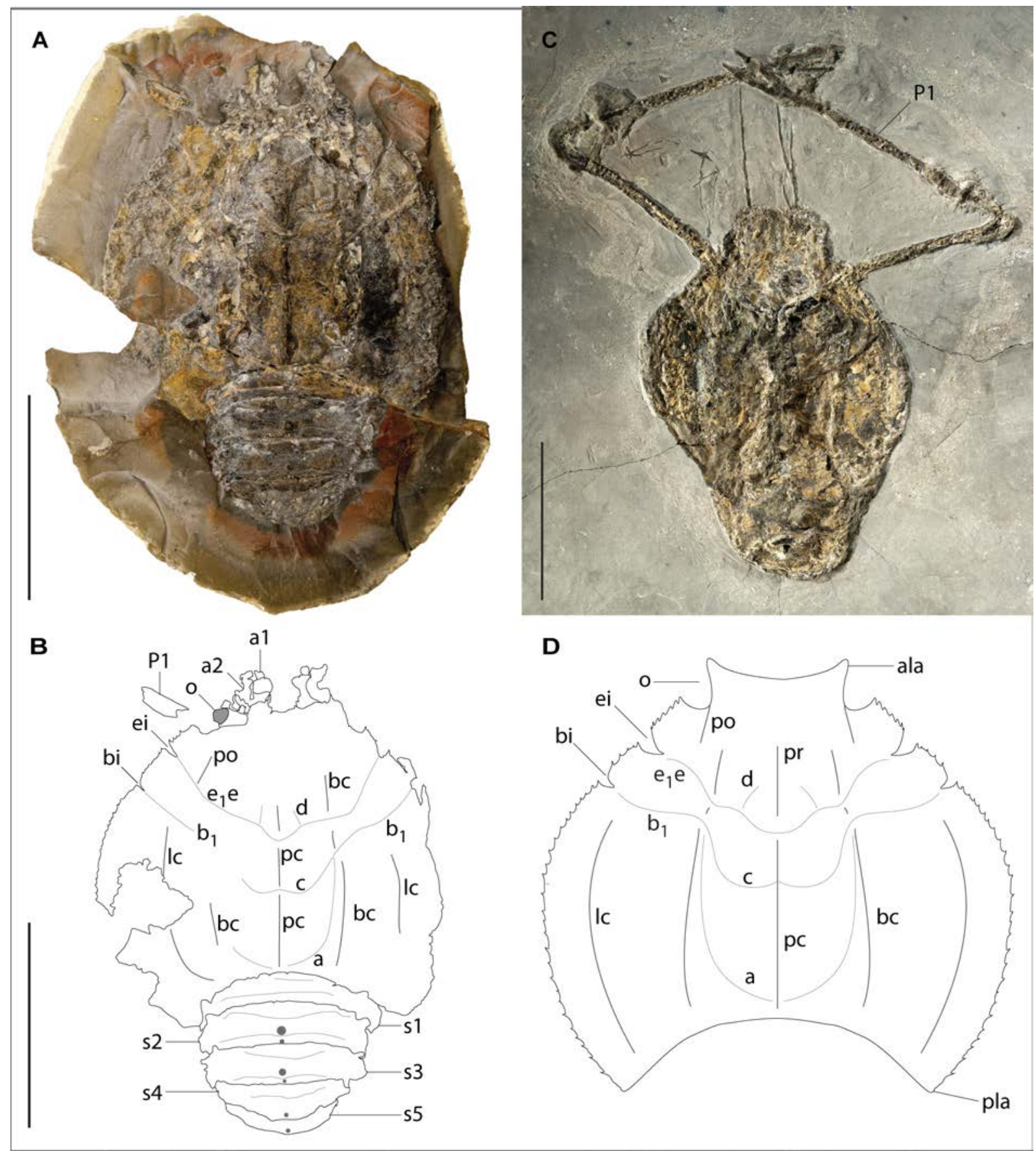

Proeryon charbonnieri Audo and Schweigert, 2018 from the Lower Callovian of La Voulte- 
sur-Rhône, France. A-B, Holotype UJF-ID.14023: photograph in cross-polarized light (A) and interpretative line-drawing (B). C, Paratype MSNM.i20703, photograph in cross-polarized light. D, Sketch of Proeryon charbonnieri cephalothoracic shield. Scale bars: $50 \mathrm{~mm}$. Photographs and sketches: D. Audo.

Proeryon charbonnieri Audo and Schweigert, 2018 du Callovien inférieur de La Voulte-surRhône, France. A-B, Holotype UJF-ID.14023: photographie en lumière polarisée analysée (A) et dessin interprétatif (B). C, Paratype MSNM.i20703, photographie en lumière polarisée analysée. D, Schéma du bouclier céphalothoracique de Proeryon charbonnieri. Barres d'échelle : 50 mm. Photographies et dessins : D. Audo. 


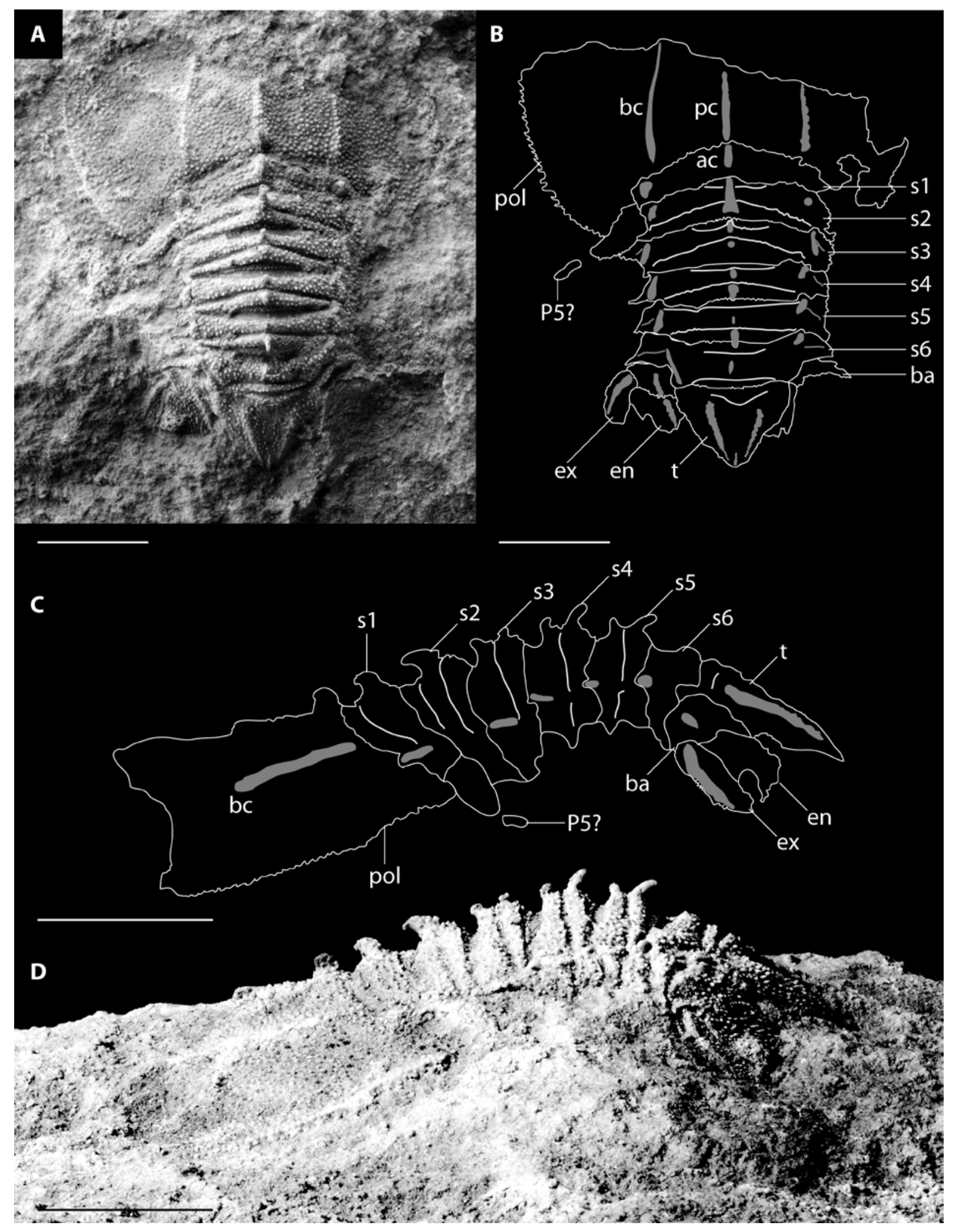

Fig. 2.

Rubber "counterpart" of the holotype of ?Proeryon erinaceus sp. nov. from the Lower Oxfordian of Calmoutier, FSL 170728: photograph of the dorsal view (A) and corresponding 
interpretative line drawing (B); interpretative line drawing of the left view (C) and corresponding photograph (D). Scale bars: $10 \mathrm{~mm}$. Photographs and sketches: D. Audo.

“Contre-empreinte” réalisée en latex de l’holotype de ?Proeryon erinaceus sp. nov. de l’Oxfordien inférieur de Calmoutier, FSL 170728 : photographie en vue dorsale (A) et dessin interprétatif correspondant (B); dessin interprétatif de la vue latérale gauche (C) et photographie correspondante (D). Barre d'échelle : $10 \mathrm{~mm}$. Photographies et dessins : D. Audo. 


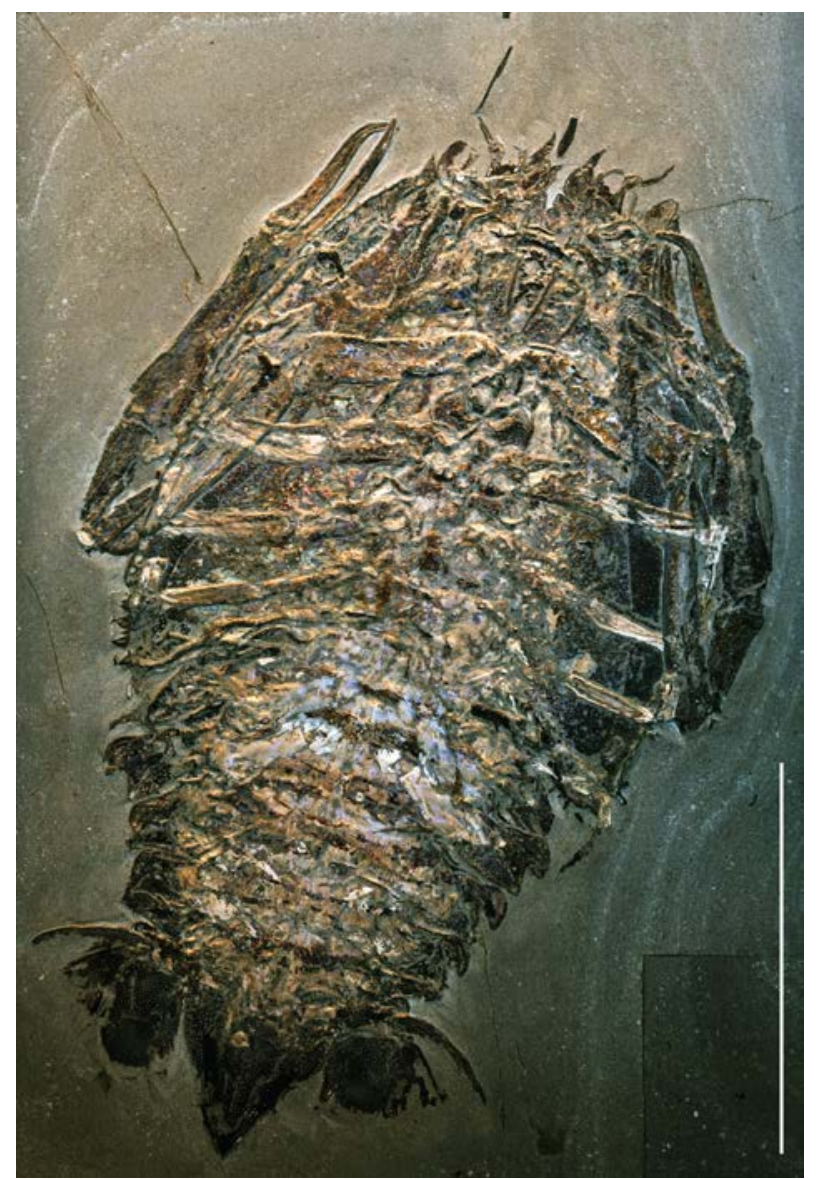

Fig. 3.

Holotype of Proeryon giganteus Beurlen, 1930 from the Lower Toarcian of Holzmaden, Urwelt Museum Hauff, no collection number, in cross-polarized light. Scale bar: 100 mm. Photograph: D. Audo.

Holotype de Proeryon giganteus Beurlen, 1930 du Toarcien inférieur d'Holzmaden, Urwelt Museum Hauff, sans numéro de collection, en lumière polarisée analysée. Barre d’échelle : 100 mm. Photographie : D. Audo. 


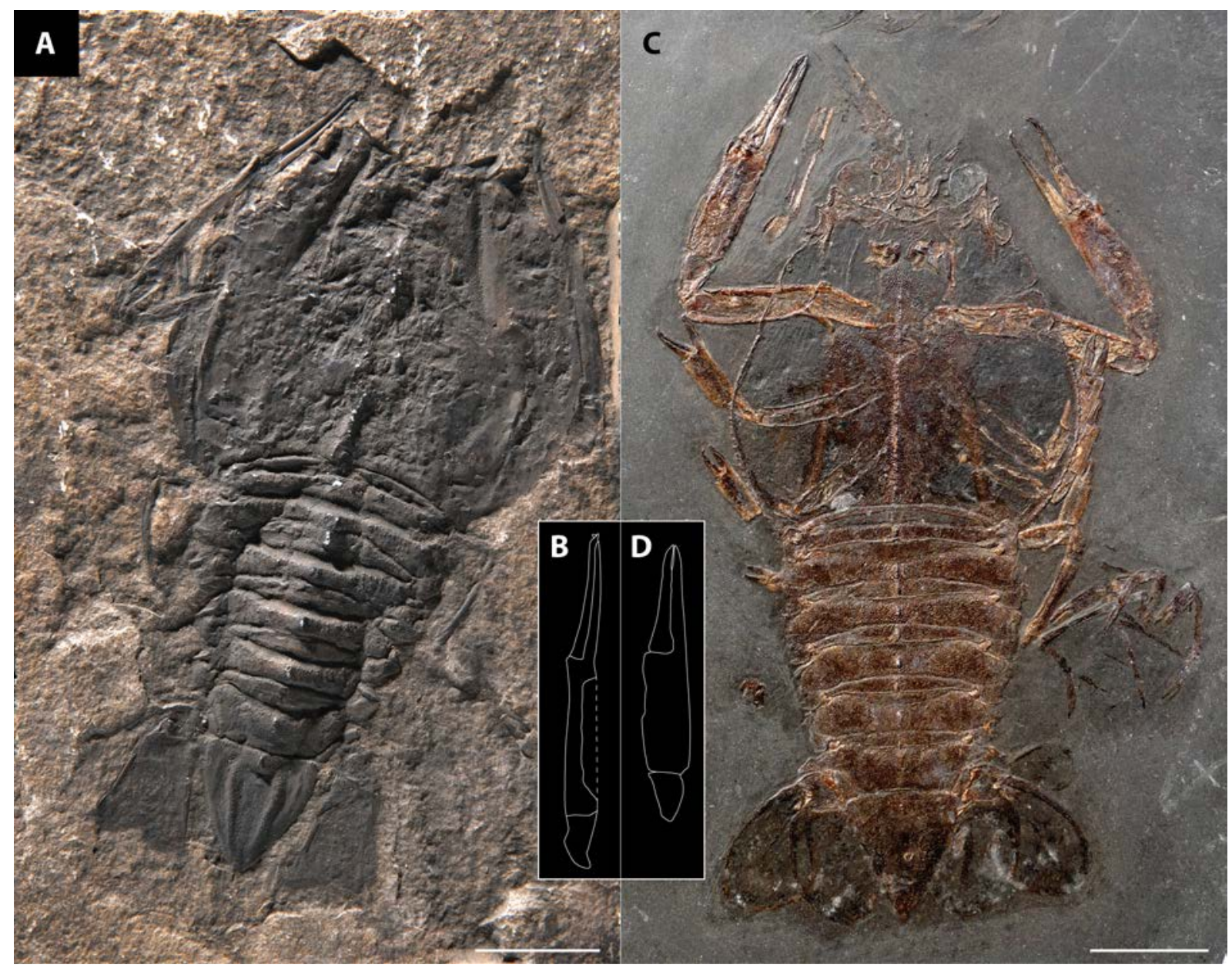

Fig. 4.

Proeryon hartmanni (Meyer, 1836) from the Lower Toarcian of Germany. A-B, Holotype: Cast of the holotype MNHN.F.A02720 (A) and interpretative line-drawing of the left first pereiopod (= thoracopod 4) (B). C-D, Specimen from the Koblenzer bed, Dieter Weber private collection, with noticeably short propodus, photograph in natural light (A) and interpretative line-drawing of the left first pereiopod (= thoracopod 4). Scale bars: $20 \mathrm{~mm}$. Photographs: C. Lemzaouda (A) and G. Schweigert (B).

Proeryon hartmanni (Meyer, 1836) Toarcien inférieur d'Allemagne. A-B, Holotype : Moulage de l'holotype MNHN.F.A02720 (A) et dessin interprétatif du premier péréiopode gauche (= thoracopode 4) (B). C-D, Spécimen des couches Toarcienne de Koblenzer, collection privée de Dieter Weber, remarquez que le propode est remarquablement court, 
photographie en lumière naturelle (A) et dessin au interprétatif du premier péréiopode gauche (= thoracopode 4). Barres d'échelle : $20 \mathrm{~mm}$. Photographies : C. Lemzaouda (A) et G. Schweigert (B). 


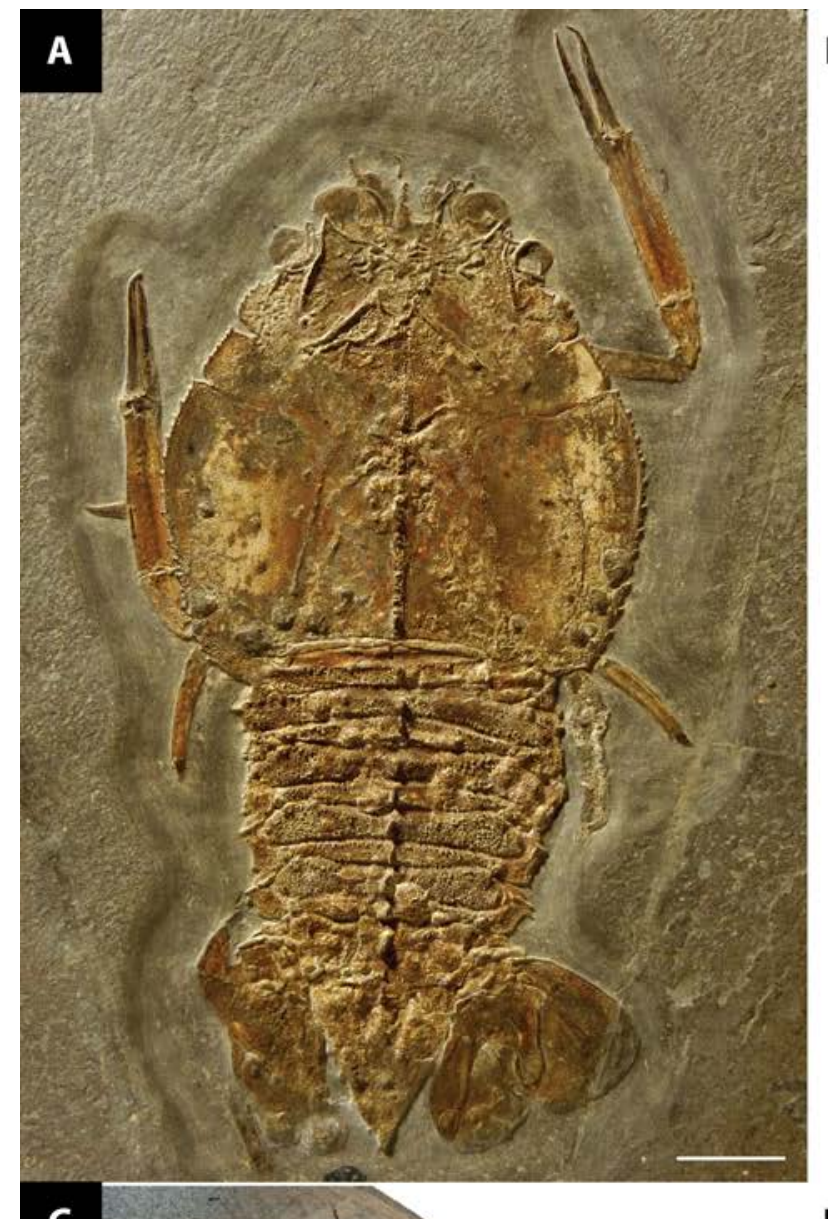

B
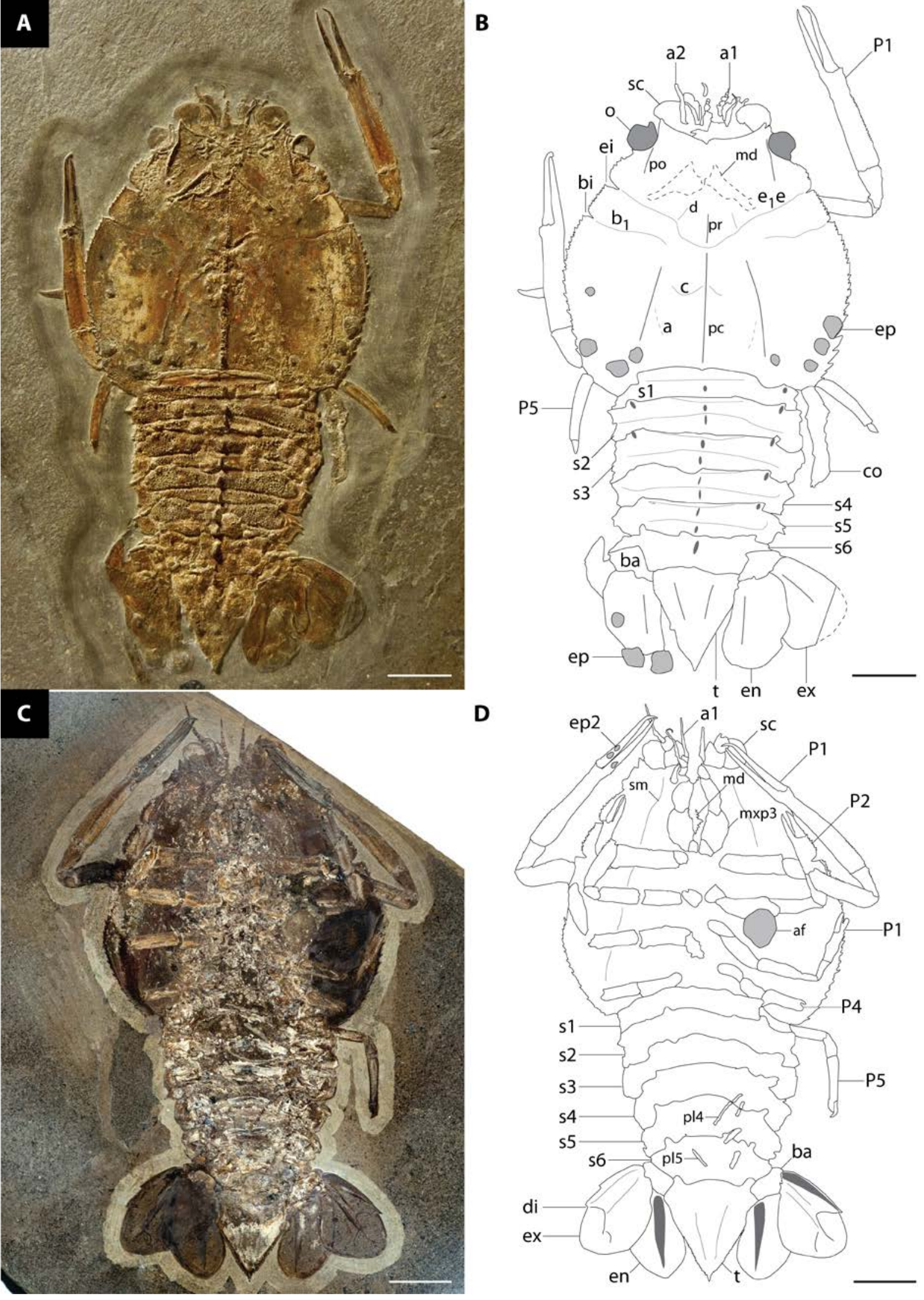

D
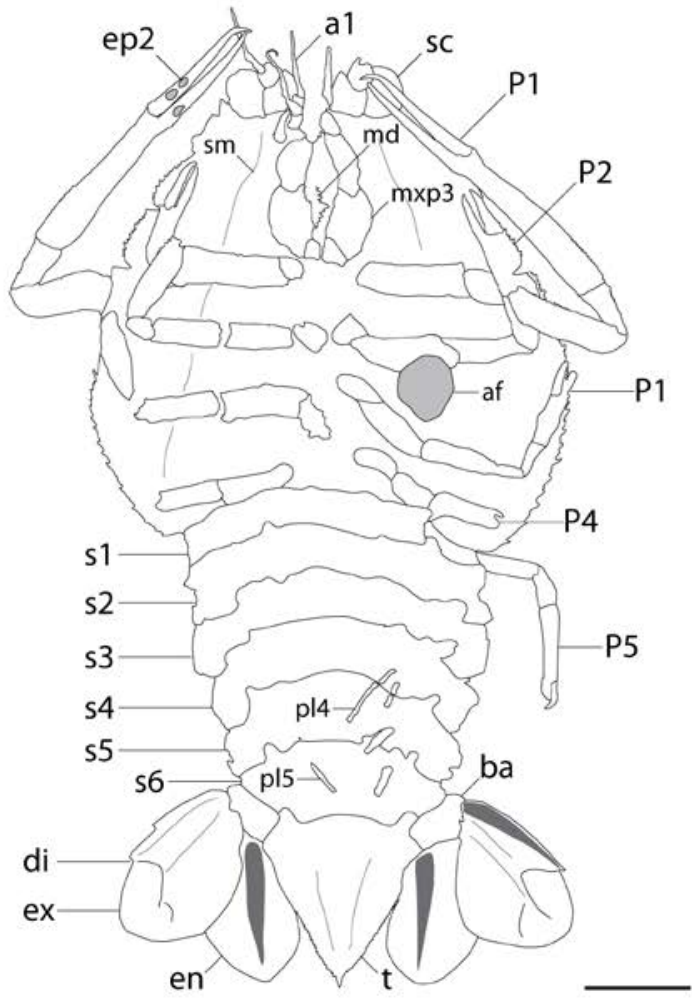
Fig. 5.

Proeryon hartmanni (Meyer, 1836) from the Lower Toarcian of Germany. A-B, Specimen from H. Tischlinger's collection: photograph in natural light (A) and interpretative linedrawing (B). C-D, Specimen SMNS 64010, photograph in cross-polarized light (C) and interpretative line-drawing (D). Scale bars: $20 \mathrm{~mm}$. Photographs and sketches: G. Schweigert (A) and D. Audo (B-D).

Proeryon hartmanni (Meyer, 1836) du Toarcien inférieur d’Allemagne. A-B, Spécimen de la collection d'H. Tischlinger : photographie en lumière naturelle (A) et dessin interprétatif (B). C-D, Spécimen SMNS 64010, photographie en lumière polarisée analysée (C) et dessin interprétatif (D). Barres d'échelle : $20 \mathrm{~mm}$. Photographies et dessins : G. Schweigert (A) et D. Audo (B-D). 

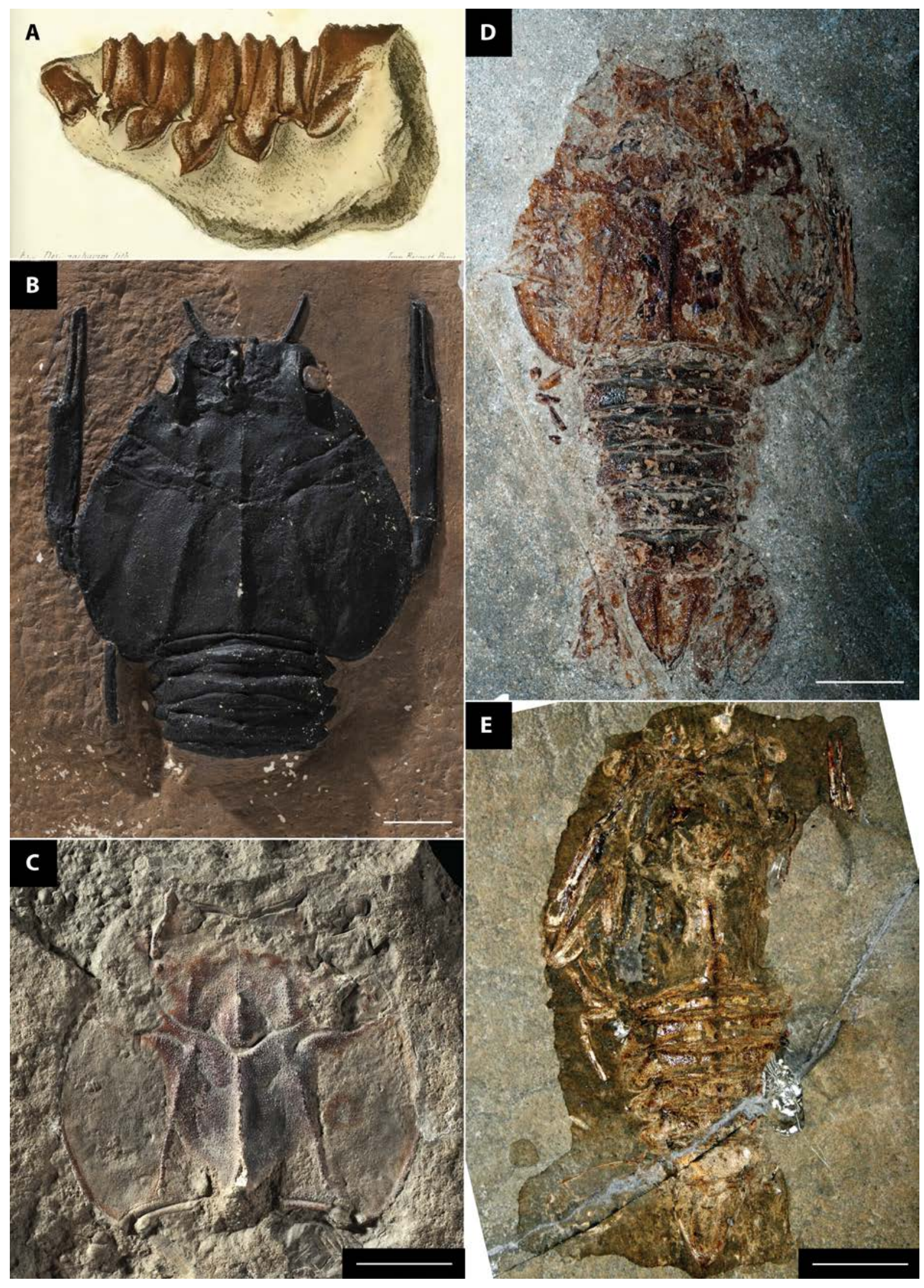


\section{Fig. 6.}

Species synonymized with Proeryon hartmanni (Meyer, 1836). A, Eryon edwardsii Morière, 1864, original illustration of the holotype. B, Eryon calvadosi Morière, 1883, cast of the one of the syntypes, MNHN.F.R03401, notice the unusually regular aspect of the specimen linked to historical cosmetic restorations. C, Coleia macrophthalma Krause, 1891, syntype MNHB X260 in natural light. D, Proeryon longiceps Beurlen, 1928, syntype from Urweltmuseum Hauff in cross-polarized light. E, Proeryon viluensis Chernyshev, 1930, syntype CNIGR Museum 2/2931. Scale bars: $20 \mathrm{~mm}$. Photographs: Public domain, scanned by Marine Biological Laboratory - Woods Hole Oceanographic Institution (A), C. Lemzaouda (B-C), D. Audo (D) and A. Sokolov (E).

Espèces mises en synonymie avec Proeryon hartmanni (Meyer, 1836). A, Eryon edwardsii Morière, 1864, illustration originale de l'holotype. B, Eryon calvadosi Morière, 1883, moulage de l'un des syntypes, MNHN.F.R03401, remarquez l'aspect inhabituellement régulier du spécimen due à des restaurations "cosmétiques» historiques. C, Coleia macrophthalma Krause, 1891, syntype MNHB X260 en lumière naturelle. D, Proeryon longiceps Beurlen, 1928, syntype du Musée Urweltmuseum Hauff en lumière polarisée analysée. E, Proeryon viluensis Chernyshev, 1930, syntype CNIGR Museum 2/2931. Barre d'échelle : $20 \mathrm{~mm}$. Photographies: Domaine publique, numérisée par le Laboratoire de Biologie Marine - Institution Océanographique de Woods Hole (A), C. Lemzaouda (B-C), D. Audo (D) et A. Sokolov (E). 


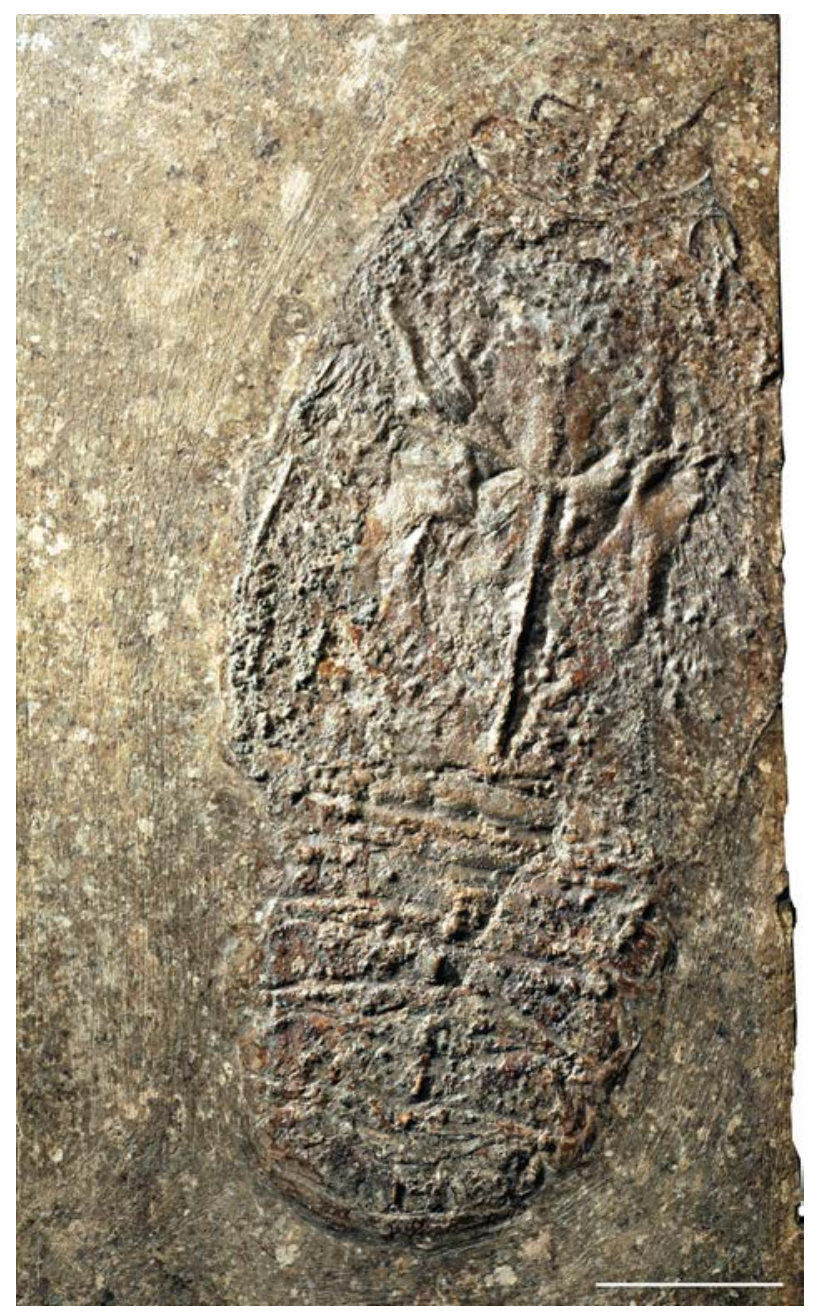

Fig. 7.

Holotype of Proeryon hauffi Beurlen, 1944 from the Lower Toarcian of Holzmaden, SNSBBSPG 1942 i 17, in natural light. Scale bar: 20 mm. Photograph: D. Audo.

Holotype de Proeryon hauffi Beurlen, 1944 du Toarcien inférieur d’Holzmaden, SNSB-BSPG 1942 i 17, en lumière naturelle. Barre d'échelle : 20 mm. Photographie : D. Audo. 

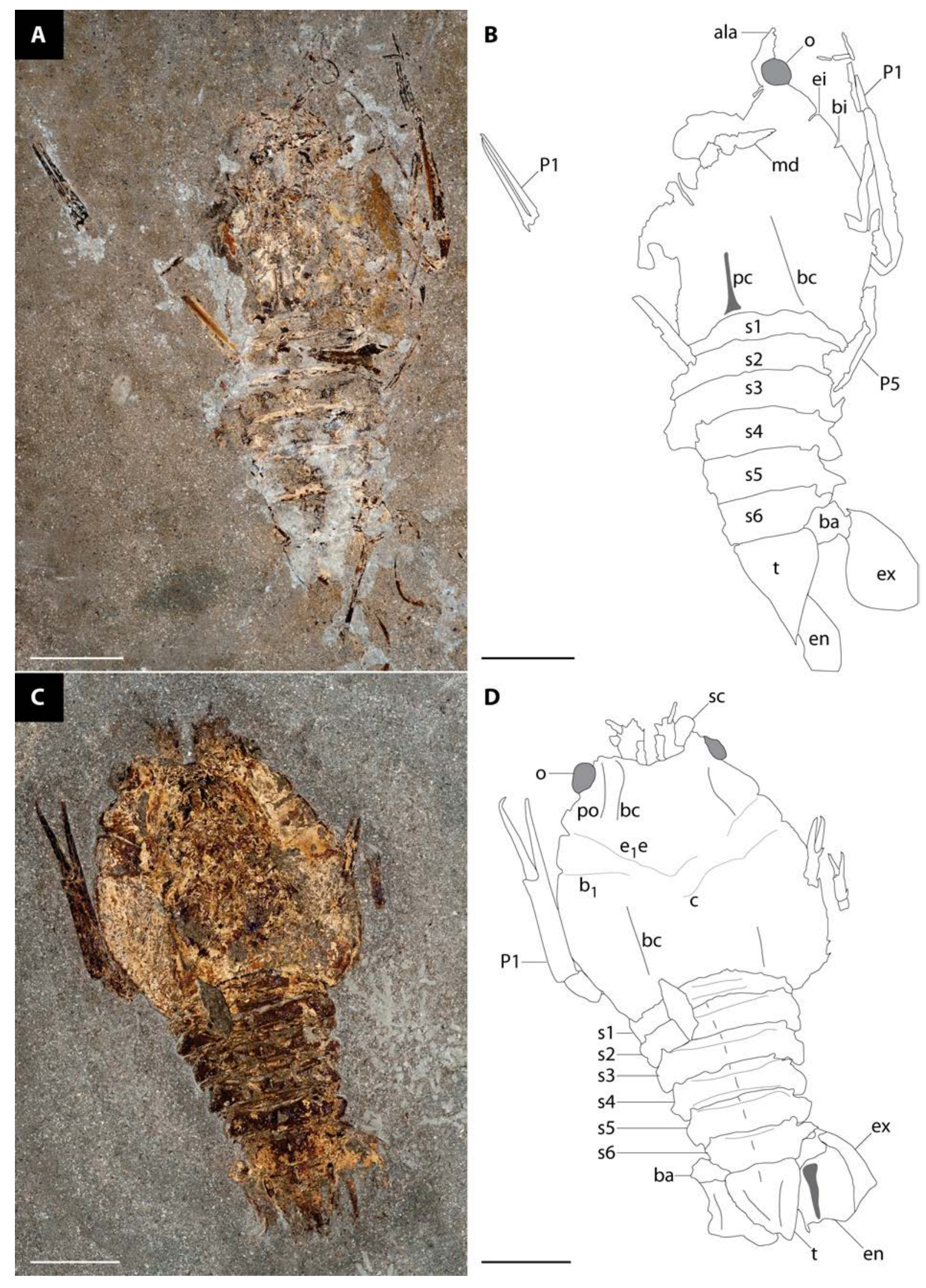
Fig. 8.

Proeryon laticaudatus Beurlen, 1928 from the Lower Toarcian of Holzmaden. A-B, Lectotype from Urweltmuseum Hauff coll., without collection number (herein designated): dorsal view, in cross-polarized light (A) and interpretative line-drawing (B). C-D, Paralectotype from Urweltmuseum Hauff coll., without collection number: dorsal view, in cross-polarized light (C) and interpretative line-drawing (D). Scale bars: $20 \mathrm{~mm}$. Photographs: D. Audo.

Proeryon laticaudatus Beurlen, 1928 du Toarcian inférieur d’Holzmaden. A-B, Lectotype du de la collection du musée Urweltmuseum Hauff, sans numéro de collection (ici désigné): vue dorsale, en lumière polarisée analysée (A) et dessin interprétatif (B). C-D, Paralectotype des collections du musée Urweltmuseum Hauff, sans numéro de collection : vue dorsale, en lumière polarisée analysée (C) et dessin interprétatif (D). Barres d'échelle : 20 mm. Photographies : D. Audo. 

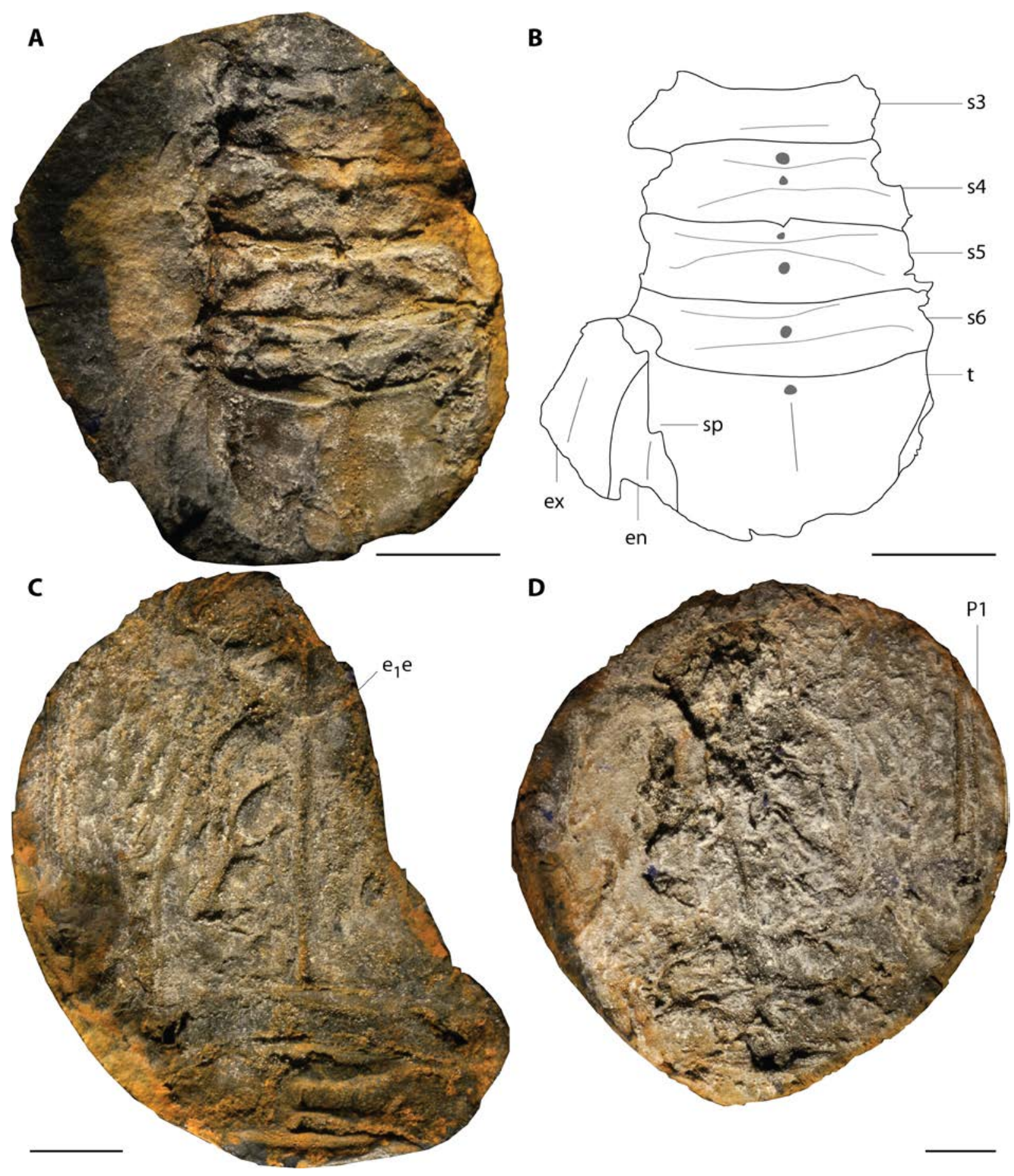

Fig. 9.

Proeryoninae from Antarctica: ?Proeryon quiltyi sp. nov. from the Middle Jurassic of Antarctica Ellsworth land: Holotype UTGD 87123 (A) and interpretative line-drawing (B), 
paratype with counterpart (C) and part (D). Scale bars: $10 \mathrm{~mm}$. Photographs and linedrawing: Isabella J. von Lichtan (A, C-D), D. Audo (B).

Proeryoninae d'Antarctique : ?Proeryon quiltyi sp. nov. du Jurassique moyen d'Antarctique de Terre d'Ellsworth : Holotype UTGD 87123 (A) et dessin interprétatif (B), paratype avec contre-empreinte (C) et empreinte (D). Barres d'échelle : $10 \mathrm{~mm}$. Photographies et dessin : Isabella J. von Lichtan (A, C-D), D. Audo (B). 

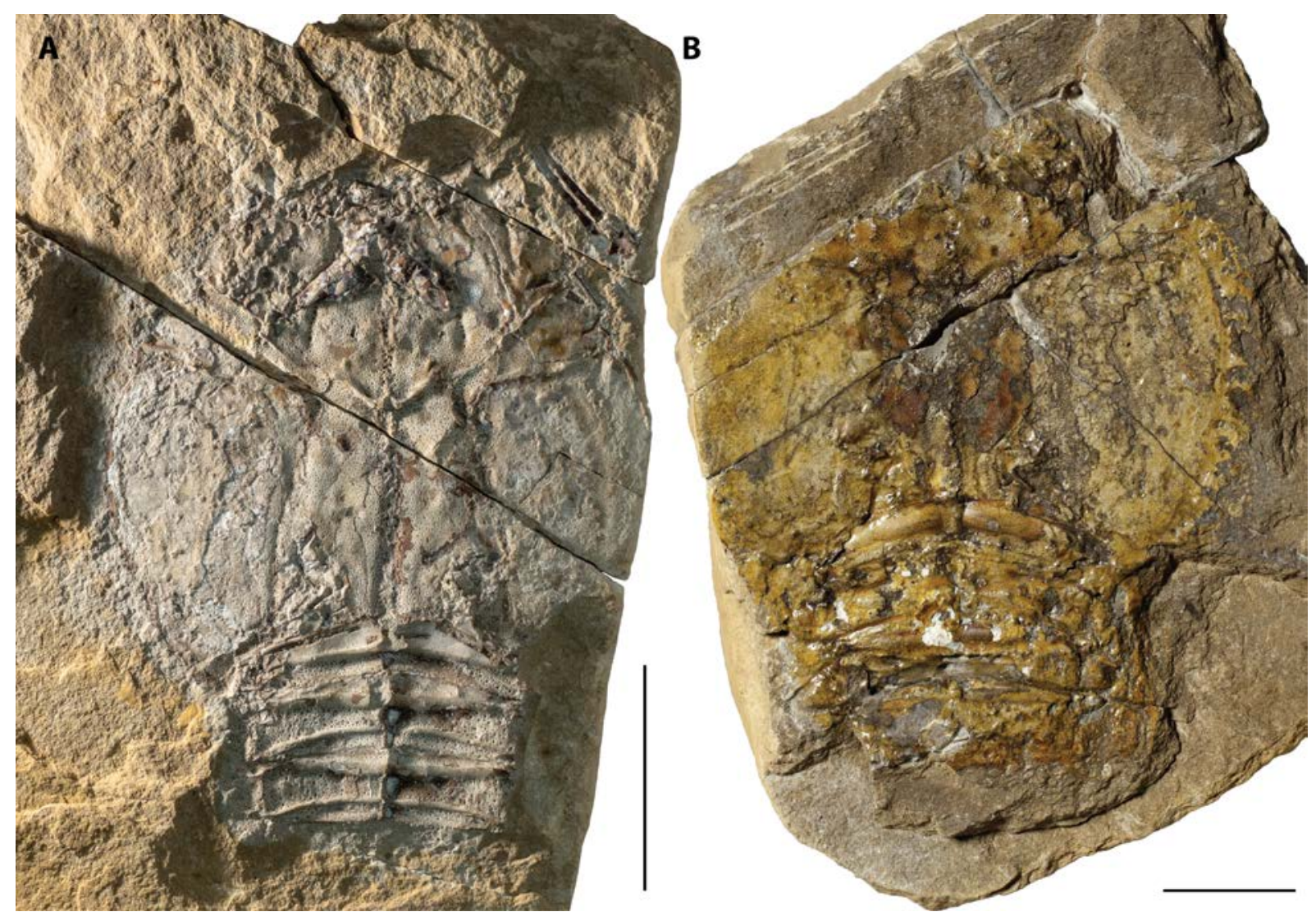

Fig. 10.

Proeryon richardsoni (Woodward, 1911) from the Pliensbachian of Dumbleton hill: Holotype F685 (A). Specimen BGS IDA 225874 (B). Scale bars: 20 mm. Photographs: Courtesy from the Cheltenham Trust and Cheltenham Borough Council (A), P.J. Shepherd, British Geological Survey (B).

Proeryon richardsoni (Woodward, 1911) du Pliensbachien de la colline de Dumbleton : Holotype F685 (A). Spécimen BGS IDA 225874 (B). Barre d'échelle : 20 mm. Photographies : fournies par le Cheltenham Trust et Cheltenham Borough Council (A), P.J. Shepherd, British Geological Survey (B). 


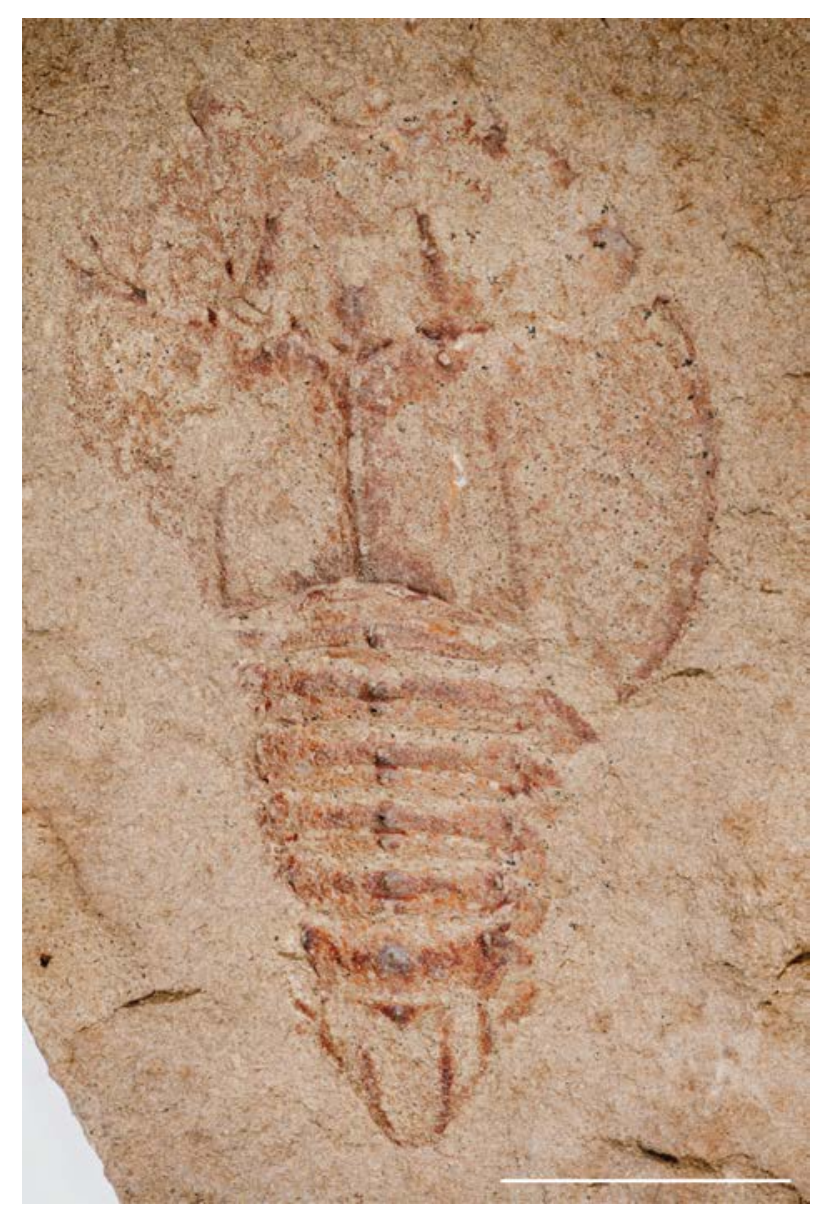

Fig. 11.

Holotype of Proeryon stoddarti (Woodward, 1881) from the Bathonian of Stonesfield, CMBK C2625 (Stoddart coll.), in natural light. Scale bar: 20 mm. Photograph: D. Audo.

Holotype de Proeryon stoddarti (Woodward, 1881) du Bathonien de Stonesfield, CMBK C2625 (coll. Stoddart), en lumière naturelle. Barre d'échelle : 20 mm. Photographie : D. Audo. 


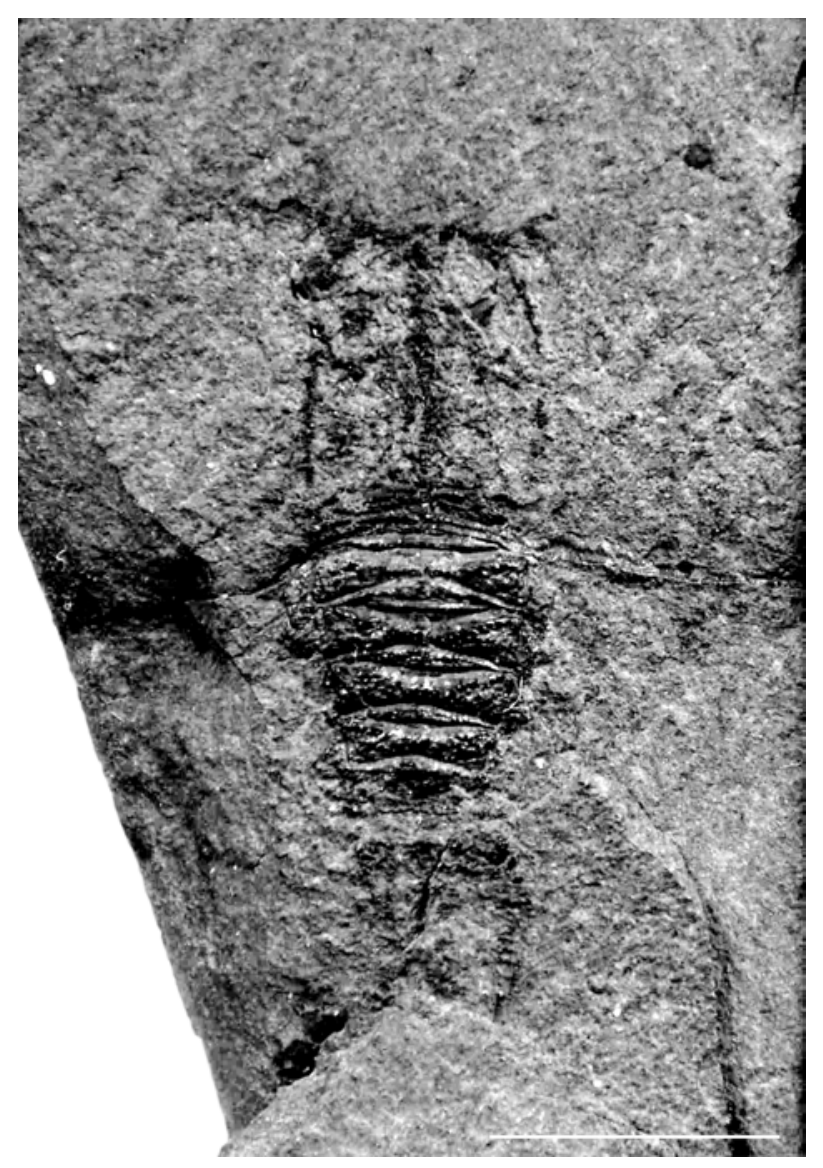

Fig. 12.

Proeryon sp.1, MHNG GEPI-28368, from the 'Neocomian' of "Feradzo”, near Châtel-SaintDenis, Fribourg, Switzerland. Scale bar: 10 mm. Photograph: Pierre-Alain Proz.

Proeryon sp.1, MHNG GEPI-28368, du 'Néocomien' de "Feradzo", près de Châtel-SaintDenis, Fribourg, Suisse. Barre d'échelle : 10 mm. Photographie : Pierre-Alain Proz. 

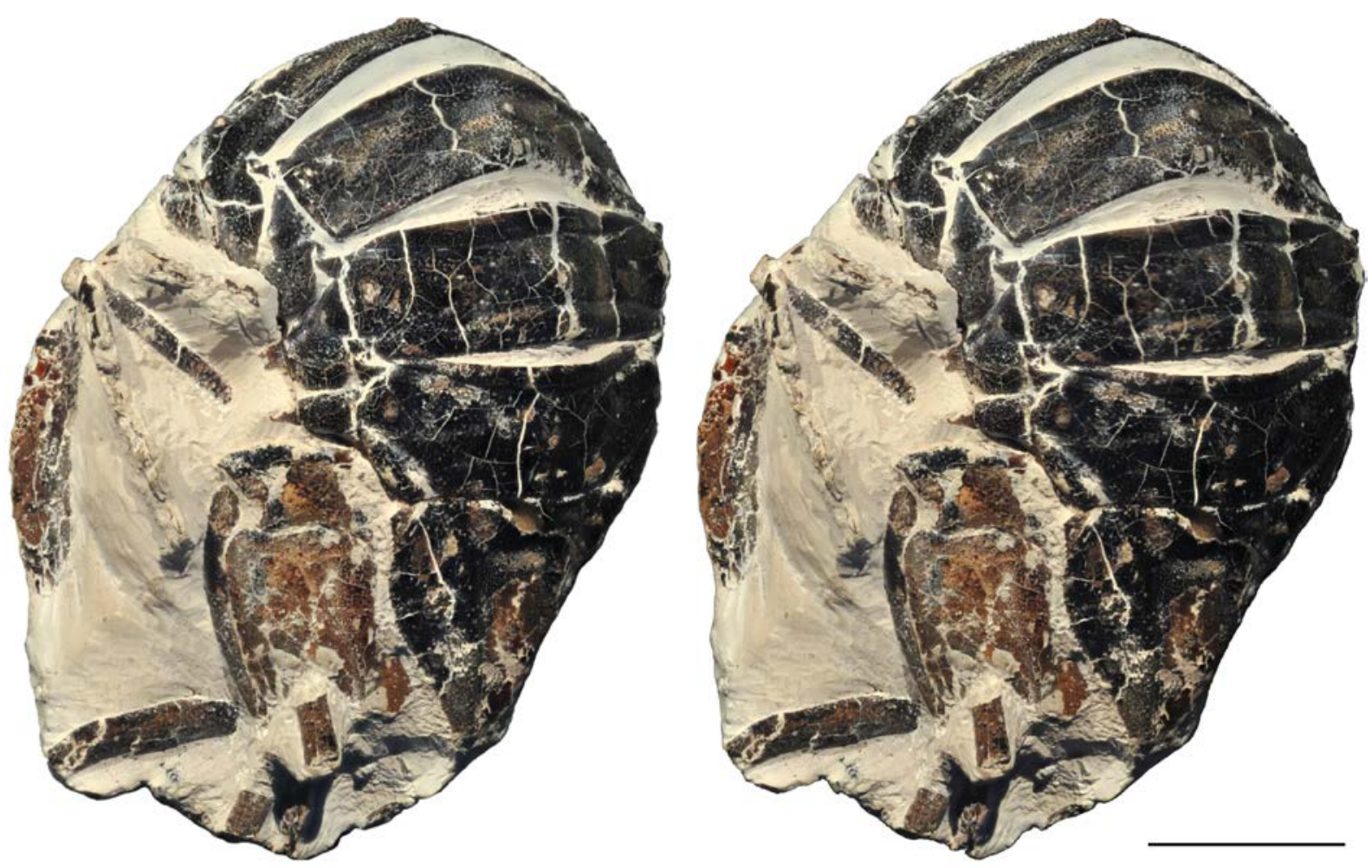

Fig. 13.

Proeryon sp.2, SMNS 66141, from the Upper Hauterivian of the Resse claypit near Hanover: Stereopair. Scale bars: 20 mm. Photograph: D. Audo.

Proeryon sp.2, SMNS 66141, de l'Hauterivien supérieur de la carrière d'argile de Resse près d’Hanovre : Stéréopaire. Barre d'échelle : 20 mm. Photographie : D. Audo. 

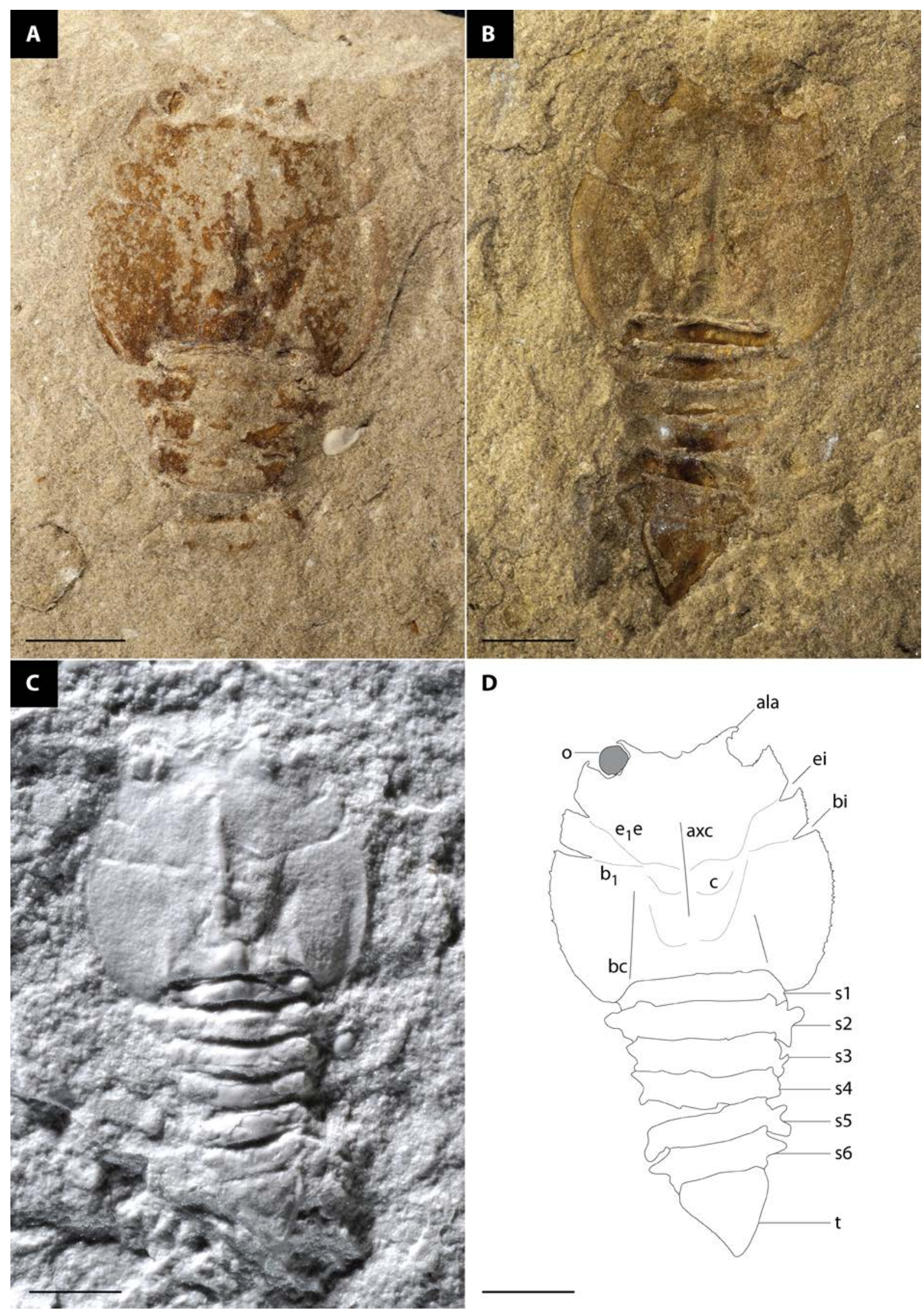


\section{Fig. 14.}

Holotype of Stonesfielderyon imitator gen. nov., sp. nov. from the Bathonian of Stonesfield, FSL 170531: A, part in cross-polarized light; B, counterpart in cross-polarized light; C, rubber cast of the counterpart; $\mathbf{D}$, interpretative line-drawing of the rubber cast. Scale bars: 10 mm. Photographs: D. Audo (A, B) and P. Loubry (C). Sketch: D. Audo.

Holotype de Stonesfielderyon imitator gen. nov., sp. nov. du Bathonien de Stonesfield, FSL 170531: A, empreinte en lumière polarisée analyse ; B, contre-empreinte en lumière polarisée analyse ; C, moulage en latex de la contre-empreinte ; D, dessin interprétatif du moulage en latex. Barre d'échelle : 10 mm. Photographies : D. Audo (A, B) et P. Loubry (C). Dessin : D. Audo.

\section{Supplementary information}

\section{Appendix 1}

Descriptive matrix of reviewed and new species

Matrice descriptive des espèces redécrites et nouvelles.

\section{Appendix 2}

List of all known species of polychelidan lobsters, including those in open nomenclature, nomina dubia and nomina nuda.

Liste de l'ensemble des espèces de polychelida, incluant celles en nomenclature ouverte, les nomina dubia et nomina nuda. 